\title{
Trophic role and top-down control of a subarctic protozooplankton community
}

\author{
Karen Riisgaard ${ }^{1}$, Rasmus Swalethorp1 ${ }^{1}$, Sanne Kjellerup ${ }^{1,2}$, Thomas Juul-Pedersen $^{2}$, \\ Torkel Gissel Nielsen ${ }^{1,2, *}$
}

${ }^{1}$ National Institute of Aquatic Resources, DTU Aqua, Section for Oceanography and Climate, Kavalergården 6, 2920 Charlottenlund, Denmark

${ }^{2}$ Greenland Climate Research Centre, Greenland Institute of Natural Resources, PO Box 570, 3900 Nuuk, Greenland

\begin{abstract}
Plankton succession was investigated in the subarctic Godthåbsfjord, Western Greenland, from March to August 2010. The trophic role of protozooplankton (ciliates and heterotrophic dinoflagellates) was evaluated with emphasis on their seasonal succession and as prey for the copepod community. The integrated protozooplankton biomass ranged between 0.1 and $4.0 \mathrm{~g}$ $\mathrm{C} \mathrm{m}^{-2}$, and was dominated by ciliates. Over the 6 mo study period, maximum potential ingestion rates of the protozooplankton ranged from 0.02 to $1.2 \mathrm{~g} \mathrm{C} \mathrm{m}^{-2} \mathrm{~d}^{-1}$, corresponding to 30 to $194 \%$ of primary production $\mathrm{d}^{-1}$ or 0.5 to $37 \%$ of phytoplankton biomass $\mathrm{d}^{-1}$. The highest copepod biomass $\left(24 \mathrm{~g} \mathrm{C} \mathrm{m}^{-2}\right.$ ) occurred in spring, with Metridia longa alone contributing up to $92 \%$ of the biomass. A grazing experiment with $M$. longa feeding on a natural plankton assemblage confirmed that this species cleared cells in the size range 10 to $60 \mu \mathrm{m}$ with an average clearance rate of $2.4 \mathrm{ml} \mu \mathrm{g}$ $\mathrm{C}^{-1} \mathrm{~d}^{-1}$. The copepod community, dominated by the genera Calanus, Metridia, Pseudocalanus, Oithona, Microsetella and Triconia/Oncaea, accounted for 72 to $93 \%$ of the copepod biomass in the spring. After the large calanoid copepod species left the surface layer, the protozooplankton increased numerically and were the most important grazers for some weeks until a late summer copepod community, dominated by cyclopoids Oithona spp., controlled the protist community. Our study indicated that protozooplankton succession is regulated by copepod grazing during most of the season, and that these protists provide an essential source of nutrition for the copepod populations.
\end{abstract}

KEY WORDS: Protozooplankton $\cdot$ Subarctic $\cdot$ Grazing $\cdot$ Metridia longa

\section{INTRODUCTION}

Greenlandic fjords support rich and diverse wildlife communities and are highly valuable ecosystems for commercial as well as cultural fishing (Hamilton et al. 2000). Climate models for the Arctic predict significant increases in temperatures, declines in the sea ice cover and acceleration of glacial melting (Stroeve et al. 2007, Comiso et al. 2008, Holland et al. 2008, Motyka et al. 2011). The Greenland fjords are major outlets of glacial runoff, and thus climate changes are likely to affect the hydrography, and possibly the food web structures, within these ecosystems (Mortensen et al. 2011). Therefore, baseline studies of the key plankton components in these areas are essential to understand climate-mediated changes in pelagic food web structure and productivity.

The Godthåbsfjord is a subarctic fjord system located next to Nuuk, the capital of Greenland. It is one of the largest fjord systems in Greenland, harbouring large populations of capelin and Atlantic cod (Smidt 1979, Storr-Paulsen et al. 2004, Bergstrøm \& Vilhjalmsson 2008). The copepod community is numerically dominated by Pseudocalanus spp., 
Microsetella spp., Oithona spp. and Metridia longa (Arendt et al. 2010, 2012, Tang et al. 2011), which is in contrast to most other Arctic regions where copepods of the genus Calanus are the most numerous species (Digby 1953, Nielsen and Hansen 1995, Rysgaard et al. 1999, Seuthe et al. 2011).

Metridia longa has not previously been recognized as an important component in the Arctic food web (e.g. Madsen et al. 2001), principally because sampling has often been conducted during the daytime, when $M$. longa is absent from the upper portion of the water column (Hays 1995, Falkenhaug et al. 1997, Daase et al. 2008). Recent studies show that $M$. longa is highly abundant during the productive season in the Godthåbsfjord (Arendt et al. 2010, 2012, Tang et al. 2011), where its high lipid content (Hopkins et al. 1984) makes this species a high quality prey item for planktivores (Pedersen \& Fossheim 2008). M. longa is considered an omnivore, feeding selectively on protozooplankton and zooplankton in the size range 5 to $300 \mu \mathrm{m}$ (Haq 1967), even when phytoplankton within this size range are available (Campbell et al. 2009).

We investigated seasonal plankton dynamics in a side branch of the Godthåbsfjord, Kapisigdlit Fjord, with emphasis on the role of protozooplankton in the food web, and the interaction between the protozooplankton and the copepod community. The latter was evaluated from maximum potential production and clearance rates given in Hansen et al. (1997) and Møller et al. (2006). Estimates of maximum potential clearance rates by Metridia longa were supported by a grazing experiment with $M$. longa feeding on a natural plankton assemblage.

\section{MATERIALS AND METHODS}

\section{Locality and sampling}

Sampling was conducted at Stn K4 $\left(64^{\circ} 25^{\prime} \mathrm{N}, 50^{\circ} 22^{\prime} \mathrm{W}\right.$; Fig. 1) on 15 occasions from 24 March to 5 August 2010, in the Kapisigdlit Fjord branch of the inner part of the Godthåbsfjord system, West Greenland. All sampling was conducted while on board the RV 'Lille Masik', except 16 to 18 June, when sampling was conducted from the RV 'Dana' (National Institute for Aquatic Resources, Denmark).
Vertical profiles of water temperature, salinity and density were obtained from the surface to ca. $10 \mathrm{~m}$ above the bottom using a CTD profiler (SBE 19 plus or 911 plus, SeaCat, and a SBE 25 SM, MicroCat). The CTD profiles were calibrated against each other, and salinity samples (collected on 24 May and 6 July 2010), were analysed on a Portosal salinometer. Water samples were collected at 1, 10, 20, 50, 75, 100, 150 and $250 \mathrm{~m}$ depths using a 51 Niskin bottle. Inorganic nutrient samples (dissolved phosphate, nitrate, nitrite, ammonium and silicate) were immediately frozen $\left(-20^{\circ} \mathrm{C}\right)$ for later analysis on a Skalar autoanalyser following the procedures of Hansen \& Koroleff (1999). The precision (analytical reproducibility) of the nutrient analyses was $0.06,0.1$, and $0.2 \mu \mathrm{M}$ for phosphate, nitrate, and silicate, respectively. Water for chlorophyll a ( $\mathrm{chl}$ a) was stored cold and dark in $10 \mathrm{l}$ containers until it was processed. On most occasions, the samples were filtered on board immediately after sampling. However on 3 occasions, samples were brought to the laboratory and filtered the following morning (i.e. after $12 \mathrm{~h}$ ). Since the chl a
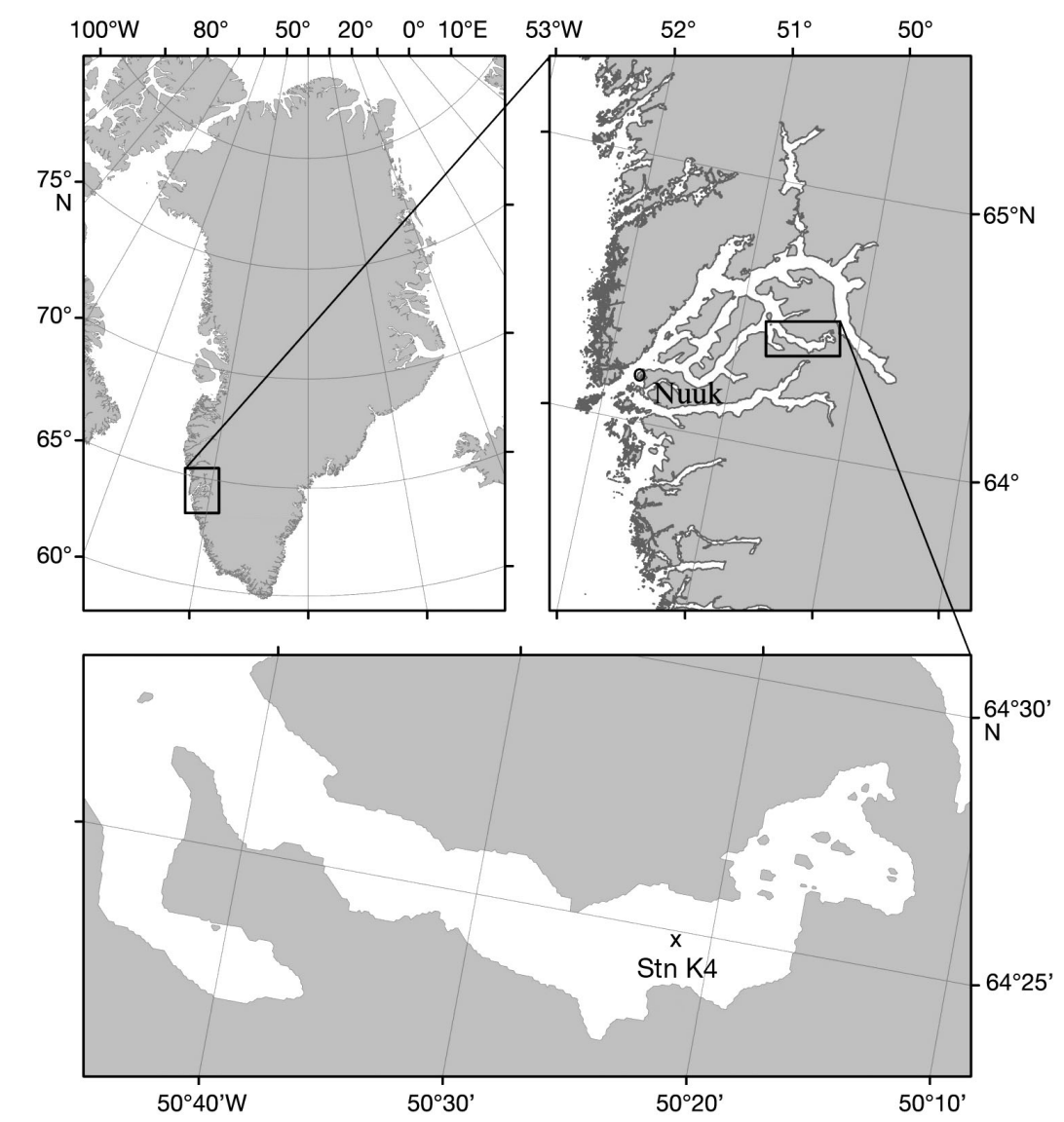

Fig. 1. Study area in West Greenland showing the location of the sampling station 
concentration was relatively stable between sampling events (i.e. the average $\mathrm{chl}$ a concentration in the upper $10 \mathrm{~m}$ across all samplings was $0.9 \pm 0.3 \mathrm{mg}$ $\mathrm{l}^{-1}$ ), we assume that this storage did not impact the chl a concentration.

\section{Phytoplankton}

Chl a concentration was determined from triplicate subsamples of 100 to $500 \mathrm{ml}$ seawater, and size fractionated on Whatman GF/F filters $(0.7 \mu \mathrm{m}$ pore size, total phytoplankton biomass) and $10 \mu \mathrm{m}$ mesh filters (from 1, 10, 20, 50 and $100 \mathrm{~m}$ depths). Filters were extracted in $96 \%$ ethanol for 12 to $24 \mathrm{~h}$ (Jespersen \& Christoffersen 1987), and then either analyzed immediately or stored at $-20^{\circ} \mathrm{C}$ for a maximum of $2 \mathrm{mo}$. Chl a was measured on a TD-700 Turner fluorometer calibrated against a chl a standard before and after acidification (Yentsch \& Menzel 1963) and converted into $\mu \mathrm{g} \mathrm{C}$ using a conversion factor of 42.7 (JuulPedersen et al. 2006).

Primary production was measured on 6 occasions using the ${ }^{14} \mathrm{C}$ incubation method (Steemann-Nielsen 1958) with a free-drifting array. Water samples from 5 , $10,20,30$ and $40 \mathrm{~m}$ depths were incubated at in situ depths for ca. $4 \mathrm{~h}$ during the day in $100 \mathrm{ml}$ Winkler glass bottles ( 1 dark and 2 light bottles at each depth); following incubation, $200 \mu \mathrm{NaH}^{14} \mathrm{CO}_{3}\left(20 \mu \mathrm{Ci} \mathrm{ml}^{-1}\right.$; DHI Denmark) was added to each of the bottles. After recovery, the samples were kept completely dark until filtration on Whatman GF/C filters. The filters were then treated with $100 \mu \mathrm{l} 1 \mathrm{M} \mathrm{HCl}$, and left to fumigate for ca. $12 \mathrm{~h}$ to remove any remaining ${ }^{14} \mathrm{C}$ on the filter. Scintillation liquid (PerkinElmer Ultima Gold) was added and the sample was mixed and left for ca. $24 \mathrm{~h}$ before analyses on a TriCarb 2800 TR liquid scintillation analyzer (PerkinElmer). In situ dissolved inorganic carbon (DIC) concentrations, measured with a CM5012 CO2 Coulometer according to Rysgaard \& Glud (2004), were applied for the calculation of primary production using the specific activity of each ${ }^{14} \mathrm{C}$ batch (DHI Denmark). The dark bottle value from each depth was subtracted from the light bottle value in order to correct for uptake of ${ }^{14} \mathrm{C}$ in the dark. In situ incoming irradiance, as photosynthetically active radiation (PAR; supplied by ASIAQ) during the deployment versus the entire day, was used to calculate the daily primary production. Primary production was integrated vertically from 0 to $45 \mathrm{~m}$, covering the euphotic zone. The influence of the different filter types used, i.e. chl a (GF/F) and primary production (GF/C), has previously been examined in the Godthåbsfjord, and no significant difference was detected between these filter types (T. Juul-Pedersen unpubl. data).

\section{Protozooplankton}

Biomass, abundance and taxonomic composition of protozooplankton were determined at 5 depths: 1,10 , $20,50 / 60$ and $100 \mathrm{~m}$. Water samples of 250 to $300 \mathrm{ml}$ were collected with a 51 Niskin bottle at each depth, gently decanted through a silicon tube into brown glass bottles and fixed in acidic Lugol's solution (final concentration of $2 \%$ ). Samples were kept cool and dark until analyses (max. of 6 mo). Depending on the cell concentration, 50 to $100 \mathrm{ml}$ subsamples were allowed to settle for $24 \mathrm{~h}$ in sedimentation chambers. All (or a minimum of 300) cells were counted using an inverted microscope (Nikon K18). Protozooplankton depth profiles were determined 9 times during the investigated period.

Protozooplankton were identified to genus level when possible. Ciliates were categorized as heterotrophic/mixotrophic. The dinoflagellates were dominated by the large heterotrophic Gyrodinium spirale (mean $=46 \%$ of the dinoflagellate biomass; range = 0 to $98 \%$ ) and the small heterotrophic G. glaucum (mean $=22 \%$ of the dinoflagellate biomass; range = 8 to $78 \%$ ). In general, all dinoflagellates $>10 \mu \mathrm{m}$ were classified as heterotrophic/mixotrophic (Hansen 2011). Cell volumes were calculated using appropriate geometric shapes without including the membranelles. To compensate for cell shrinkage due to Lugol's solution preservation, cell volumes were increased by a factor of 1.3 (Stoecker et al. 1994). The bio-volumes $(V)$ were converted to carbon (pg C) using the volume-to-carbon conversion factors given in Table 1.

Table 1. Volume $(V)$ to carbon (pg C cell ${ }^{-1}$ ) conversion factors used for heterotrophic protists

\begin{tabular}{|c|c|c|}
\hline & Conversion factor & Source \\
\hline $\begin{array}{l}\text { Aloricate } \\
\text { ciliates }\end{array}$ & $\begin{array}{l}\log \left(\mathrm{pg} \mathrm{C} \mathrm{cell}^{-1}\right)=-0.639 \\
\quad+0.984 \log (V)\end{array}$ & $\begin{array}{l}\text { Putt \& Stoecker (1989), modified by } \\
\text { Menden-Deuer \& Lessard (2000) }\end{array}$ \\
\hline $\begin{array}{l}\text { Loricate } \\
\text { ciliates }\end{array}$ & $\begin{array}{l}\log \left(\mathrm{pg} C \mathrm{cell}^{-1}\right)=-0.168 \\
\quad+0.841 \log (V)\end{array}$ & $\begin{array}{l}\text { Verity \& Langdon (1984), } \\
\text { Menden-Deuer \& Lessard (2000) }\end{array}$ \\
\hline $\begin{array}{l}\text { Dino- } \\
\text { flagellates }\end{array}$ & $\begin{array}{l}\log \left(\mathrm{pg} \mathrm{C} \mathrm{cell}{ }^{-1}\right)=-0.353 \\
\quad+0.864 \log (V)\end{array}$ & Menden-Deuer \& Lessard (2000) \\
\hline
\end{tabular}


Identification of ciliates and dinoflagellates to species, genus or morphotypes was based on Nielsen \& Hansen (1999). During enumeration, ciliates and dinoflagellates were identified to lowest taxonomic level possible and divided into size classes covering $10 \mu \mathrm{m}$ ranges of equatorial spherical diameter (ESD) starting with 10 to $20 \mu \mathrm{m}$. ESD and cell volume are related by: cell volume $=\pi / 6 \times \mathrm{ESD}^{3}$.

Rates of protozooplankton maximum potential clearance rates were calculated according to the equation in Hansen et al. (1997) for ciliates:

$$
\log \left(C_{\max }\right)=1.491-0.23 \log \left(P_{\mathrm{vol}}\right)
$$

and for heterotrophic dinoflagellates:

$$
\log \left(C_{\max }\right)=0.851-0.23 \log \left(P_{\mathrm{vol}}\right)
$$

where $C_{\max }$ is the maximum potential clearance rate, and $P_{\text {vol }}$ is the cell volume in $\mu^{3}$. $C_{\max }$ was normalized to in situ temperatures (ranging between 0.5 and $13^{\circ} \mathrm{C}$ ) by using a $Q_{10}$ factor of 2.8 (reviewed in Hansen et al. 1997). Maximum potential ingestion rate, $I$ ( $\mu \mathrm{g} \mathrm{C}$ cell $^{-1} \mathrm{~d}^{-1}$ ) was calculated from sizespecific maximum potential clearance rates and the in situ chl a concentration:

$$
I=C_{\max } \times d
$$

where $d\left(\mu g \mathrm{C}^{-1}\right)$ is the phytoplankton density. Ciliates were assumed to graze on the chl a fraction $<10 \mu \mathrm{m}$, while heterotrophic dinoflagellates were assumed to graze on the chl a fraction $>10 \mu \mathrm{m}$ (Jakobsen \& Hansen 1997). Production ( $\mu g \mathrm{C} \mathrm{l}^{-1} \mathrm{~d}^{-1}$ or $\mathrm{g} \mathrm{C} \mathrm{m}^{-2} \mathrm{~d}^{-1}$ ) of ciliates and dinoflagellates was estimated from $I$ using an average gross growth efficiency of 0.33 (Hansen et al. 1997, 2000).

\section{Copepod biomass}

Copepods were collected in 5 depth strata $(0$ to 50,50 to 100,100 to 150,150 to 200 , and 200 to $235 \mathrm{~m})$ with a Multinet $(50 \mu \mathrm{m}$ mesh, Hydrobios type mini). The nets were hauled at a speed of 0.2 to $0.3 \mathrm{~m} \mathrm{~s}^{-1}$, and samples were immediately preserved in buffered formalin (4\% final concentration). Sampling was conducted around 18:00 h local time. Samples containing high numbers of copepods were split by volumes into subsamples. In each sample and subsample, all nauplii and copepodite stages were identified to species or genus level, and length was measured for up to 10 individuals of each stage. Biomass of the different copepod species was calculated based on measurements of prosome length, and length/carbon relationships from the literature (Table 2).

\section{Metridia longa grazing experiment}

Seawater was collected on 28 July 2010 from 20 m depth with a 301 Niskin bottle and transferred gently via a silicon tube into a 251 dark carboy. The carboy

\begin{tabular}{|c|c|c|c|c|c|}
\hline Taxon & $a$ & $b$ & Source & Stage & Units $(L)$ \\
\hline Acartia spp. ${ }^{\mathrm{a}}$ & $1.11 \times 10^{-11}$ & 2.92 & Berggreen et al. (1988) & $\mathrm{C} 1-\mathrm{C} 6$ & $\mu \mathrm{m}$ \\
\hline Calanus finmarchicu $^{\mathrm{a}}$ & $4.8 \times 10^{-3}$ & 3.5687 & Madsen et al. (2001) & $\mathrm{C} 1-\mathrm{C} 6$ & $\mathrm{~mm}$ \\
\hline Calanus glacialis $^{\mathrm{a}}$ & $4.8 \times 10^{-3}$ & 3.5687 & Madsen et al. (2001) & $\mathrm{C} 1-\mathrm{C} 6$ & $\mathrm{~mm}$ \\
\hline Calanus hyperboreus ${ }^{\mathrm{a}}$ & $1.4 \times 10^{-3}$ & 3.3899 & Hirche \& Mumm (1992) & $\mathrm{C} 1-\mathrm{C} 6$ & $\mathrm{~mm}$ \\
\hline Centropages spp. ${ }^{\mathrm{b}}$ & $1.78 \times 10^{-2}$ & 2.45 & Klein Breteler et al. (1982) & $\mathrm{C} 1-\mathrm{C} 6$ & $\mathrm{~mm}$ \\
\hline Centropages spp. ${ }^{\mathrm{b}}$ & $1.45 \times 10^{-2}$ & 2.24 & Klein Breteler et al. (1982) & N1-N6 & $\mathrm{mm}$ \\
\hline Metridia spp. ${ }^{\mathrm{a}}$ & $6.05 \times 10^{-3}$ & 3.0167 & Hirche \& Mumm (1992) & $\mathrm{C} 1-\mathrm{C} 6$ & $\mathrm{~mm}$ \\
\hline Microcalanus spp. $^{\text {a }}$ & $9.47 \times 10^{-10}$ & 2.16 & Sabatini \& Kiørboe (1994) & $\mathrm{C} 1-\mathrm{C} 6$ & $\mu \mathrm{m}$ \\
\hline Microsetella spp. $^{\mathrm{a}}$ & $2.65 \times 10^{-9}$ & 1.95 & Uye et al. (2002) & N1-C6 & $\mu \mathrm{m}$ \\
\hline Oithona spp. ${ }^{\mathrm{a}}$ & $9.47 \times 10^{-10}$ & 2.16 & Sabatini \& Kiørboe (1994) & $\mathrm{C} 1-\mathrm{C} 6$ & $\mu \mathrm{m}$ \\
\hline Oithona spp. ${ }^{\mathrm{a}}$ & $5.545 \times 10^{-11}$ & 2.71 & Sabatini \& Kiørboe (1994) & N1-N6 & $\mu \mathrm{m}$ \\
\hline Oncaea spp. ${ }^{\text {a }}$ & $2.51 \times 10^{-11}$ & 2.9 & Satapoomin (1999) & $\mathrm{C} 1-\mathrm{C} 6$ & $\mu \mathrm{m}$ \\
\hline Paraeuchaeta spp. ${ }^{\mathrm{c}}$ & 3.1107 & 1.8633 & K. Tönnesson unpubl. data & N1-C6 & $\mathrm{mm}$ \\
\hline Pseudocalanus spp. ${ }^{a}$ & $6.12 \times 10^{-11}$ & 2.7302 & Klein Breteler et al. (1982) & $\mathrm{C} 1-\mathrm{C} 6$ & $\mu \mathrm{m}$ \\
\hline Calanus spp. and Metridia spp. ${ }^{a}$ & $4.29 \times 10^{-9}$ & 2.05 & Hygum et al. (2000) & N1-N6 & $\mu \mathrm{m}$ \\
\hline Other nauplii $^{a}$ & $3.18 \times 10^{-12}$ & 3.31 & Berggreen et al. (1988) & N1-N6 & $\mu \mathrm{m}$ \\
\hline
\end{tabular}
was stirred gently, nutrients were added $(15 \mu \mathrm{M}$

Table 2. Length $(L)$ to carbon (mg C) conversion factors used for copepod nauplii (N1-N6) and copepodites (C1-C6) 
$\mathrm{NH}_{4} \mathrm{Cl}$ and $1 \mu \mathrm{M} \mathrm{Na} \mathrm{HPO}_{4}$ ), and seawater was inverse filtered via a silicon tube through $200 \mu \mathrm{m}$ mesh to remove mesozooplankton, and to fill 42 transparent $600 \mathrm{ml}$ polycarbonate bottles.

Metridia longa were collected using a $200 \mu \mathrm{m}$ WP2 net. One actively swimming adult female $M$. longa was added to each of the 28 polycarbonate bottles. Fourteen additional bottles without copepods were used as controls. To ensure that copepods cleared on average $<30 \%$ of the prey, half of the experimental and control bottles were incubated for $12 \mathrm{~h}$, and the other half for $24 \mathrm{~h}$. Bottles were incubated in darkness at $5^{\circ} \mathrm{C}$ (in situ temperature was $3.2^{\circ} \mathrm{C}$ ) and rotated by hand every $6 \mathrm{~h}$. Dark incubation was chosen since $M$. longa undergo diel vertical migrations and feed during the night (Hays 1995). As soon as the experiment was terminated, triplicate subsamples of $100 \mathrm{ml}$ were removed from the bottles for determination of chl a concentration. For protozooplankton analyses, $100 \mathrm{ml}$ subsamples were fixed in acidic Lugol's solution in a final concentration of $2 \%$.

Metridia longa clearance rates $\left(\mathrm{ml} \mu \mathrm{g} \mathrm{C}^{-1} \mathrm{~d}^{-1}\right)$ were calculated from Frost (1972) when prey growth rates differed significantly from the controls ( $t$-test, $\mathrm{p}<$ 0.05 ). Clearance rate on protozooplankton was calculated for 4 size classes of ciliates, 1 size class of dinoflagellates and 2 size classes of nanoflagellates (Table 3). A minimum of 450 cells were measured for each size class. Clearance rate on phytoplankton was calculated using chl a as a proxy. Clearance rates were converted to in situ temperatures by using a $Q_{10}$ factor of 2.8 (Hansen et al. 1997, 2000).

\section{Copepod community grazing}

Clearance capacity of the copepod community was estimated from maximum specific clearance rates, assuming that the copepod population was not food-

Table 3. Average equatorial spherical diameter (ESD; $\mu \mathrm{m})$, range, standard deviation (SD) and number of cells (n) measured within the different size classes of the grazing experiment

\begin{tabular}{|lcccr|}
\hline & $\begin{array}{c}\text { Average } \\
\text { ESD }(\mu \mathrm{m})\end{array}$ & $\begin{array}{c}\text { ESD range } \\
(\mu \mathrm{m})\end{array}$ & $\begin{array}{c}\mathrm{SD} \\
(\mu \mathrm{m})\end{array}$ & $\mathrm{n}$ \\
\hline Ciliates & 11.7 & $7-15$ & 1.8 & 1975 \\
& 21.2 & $15-30$ & 4.4 & 2375 \\
& 34.9 & $30-40$ & 2.8 & 634 \\
Dinoflagellates & 50.3 & $40-60$ & 5.7 & 917 \\
Nanoflagellates & 33.3 & $25-50$ & 5.6 & 865 \\
& 5.5 & $3-4$ & 0.4 & 455 \\
& 5.4 & $5-6$ & 0.2 & 483 \\
\hline
\end{tabular}

saturated. Maximum specific clearance rate $(F)$ of Metridia longa was estimated according to Hansen et al. $(1997,2000)$ :

$$
\log (F) \times 10^{5}=\log (1.5753)-0.23 \log (V)
$$

where $V$ is the copepod body volume in $\mu^{3}$. Since $M$. longa undertake pronounced diel vertical migration and only visit the surface at night, $M$. longa maximum potential clearance capacity is only realized in the upper $50 \mathrm{~m}$ for $6 \mathrm{~h}$ per day, i.e. around midnight (S. Kjellerup unpubl. data). Maximum potential clearance was converted to in situ temperatures in the upper $50 \mathrm{~m}$ of the water column using a $Q_{10}$ factor of 2.8 (Hansen et al. 1997, 2000).

\section{Protozooplankton}

The maximum potential clearance rates of Calanus spp. and other copepods (i.e. Pseudocalanus, Oithona, Centropages and Microcalanus) were estimated according to Møller et al. (2006):

$$
\log (F)=1.16-0.45 \log (W), \mathrm{r}^{2}=0.73
$$

where $W$ is the copepod biomass ( $\mu \mathrm{g} \mathrm{C}$ ), assuming that they were distributed evenly throughout the water column. Maximum potential clearance rates were converted to in situ temperatures using a $Q_{10}$ factor of 2.8 (Hansen et al. 1997, 2000). From March until breakup of ice in the Kapisigdlit River around 20 June 2010, $Q_{10}$ was calculated in the 0 to $100 \mathrm{~m}$ depth stratum. Thereafter, Calanus spp. and other copepods were distributed below the warm and fresh surface water and thus $Q_{10}$ was calculated in the 20 to $100 \mathrm{~m}$ depth stratum. The small copepods Microsetella spp. and Triconia/Oncaea spp. were not included in the grazing estimates since they both have morphologies and feeding strategies suited for solid substrata such as marine snow (Koski et al. 2007).

\section{RESULTS}

\section{Hydrography}

Sampling was initiated in March when the water column was well-mixed with cold, saline, nutrientrich water throughout the euphotic zone (Fig. 2, Table 4). The chl a concentration was low (0.5 to

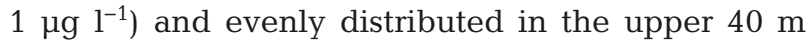
(Fig. 2C). In late April, a weak halocline was established (Fig. 2B) and additional heat was trapped in the surface layer (Fig. 2A). The stratification stimu- 
lated phytoplankton growth, which then quickly depleted the nitrate to below 0.5 $\mu \mathrm{M}$ in association with the peak of the first phytoplankton bloom of $3 \mu \mathrm{g} \mathrm{chl} \mathrm{a} \mathrm{l}^{-1}$ (Fig. $2 \mathrm{C}$ ).

In May, melt water was added to the surface layer as runoff from land, and culminated in the seasonal pulse of fresh water following the breakup of ice in the Kapisigdlit River around 20 June 2010. Thereafter, the surface salinity rapidly decreased from 31 to 16 by the beginning of August. The melt water established a strong halocline, strengthened by a thermocline due to warming of the freshwater surface plume to above $13^{\circ} \mathrm{C}$ on the last sampling day (5 August 2010). After the depletion of nitrate above the pycnocline, a subsurface bloom developed with a peak

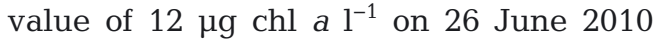
(Fig. 2).

\section{Nutrients}

High concentrations of nutrients (i.e. phosphorus, nitrate and silicate) were measured in the upper $100 \mathrm{~m}$ of the water column at the initiation of the investigation (data not shown). During the first part of the investigation, the average nitrate concentration in the upper $50 \mathrm{~m}$ stratum decreased from $6.8 \pm 0.3 \mu \mathrm{M}$ to $0.5 \pm 0.3$ $\mu \mathrm{M}$ as a result of increased stratification and the developing phytoplankton bloom (Fig. 2C). The overall phosphorus and silicate distributions (Table 4) and succession mirrored that illustrated by nitrate (Fig. $2 \mathrm{C}$ ), but were not fully depleted in the euphotic zone. In association with the breakup of ice in the Kapisigdlit River, a
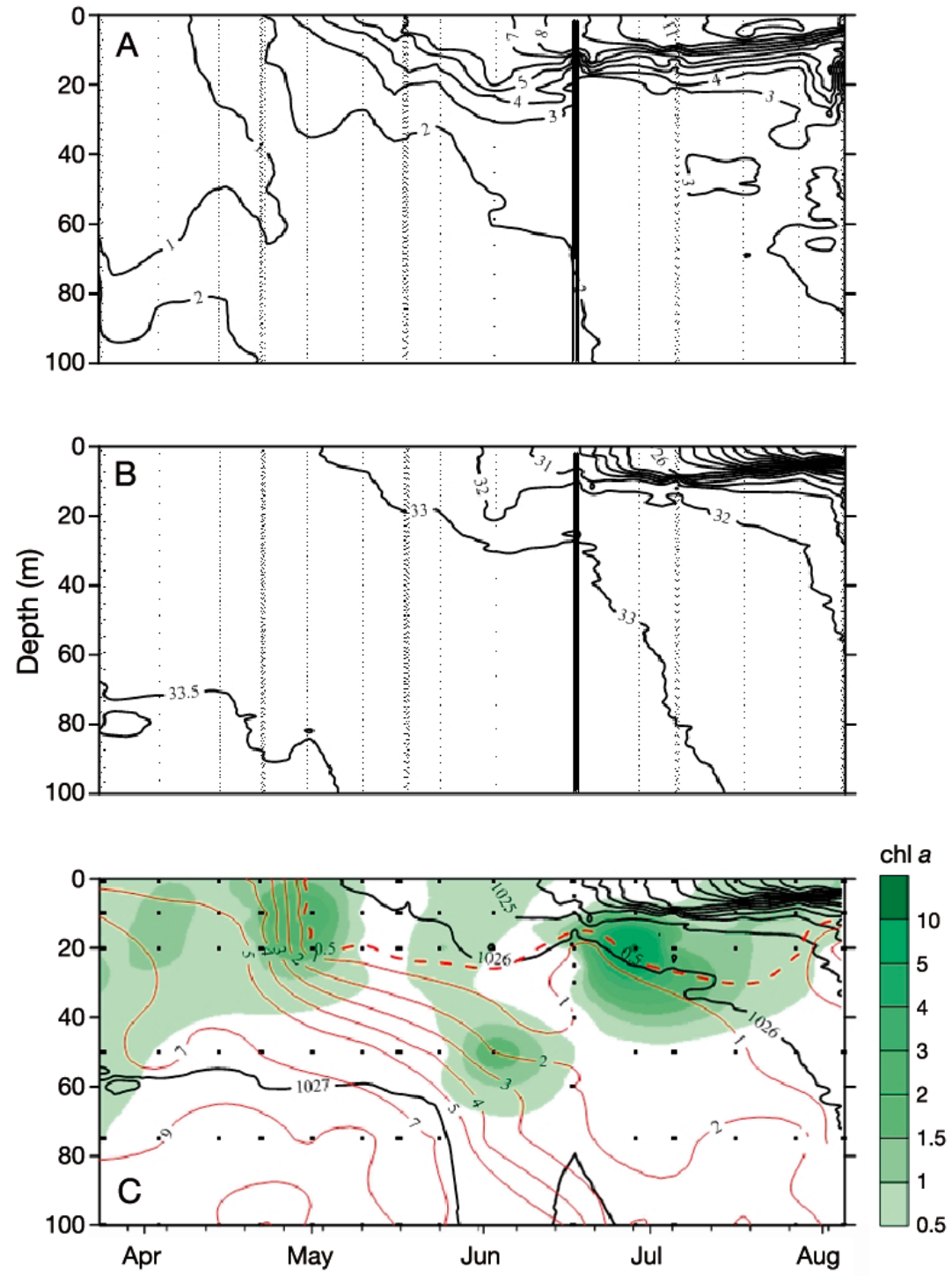

Fig. 2. Water column characteristics over the investigation period. (A) Temperature $\left({ }^{\circ} \mathrm{C}\right)$, (B) salinity and $(\mathrm{C})$ density $\left(\mathrm{kg} \mathrm{m}^{-3}\right)$ overlaid with chl a concentrations ( $\mu \mathrm{g} \mathrm{l}^{-1}$, green shading) and concentrations of the limiting nutrient, nitrate $(\mu \mathrm{M})$, displayed as red isolines (detection limit $0.5 \mu \mathrm{M}$, red dashed line). Points represent sampling depths. The vertical black line indicates breakup of the ice in the fjord

Table 4. Concentrations $(\mu \mathrm{M})$ of nutrients (mean $\pm \mathrm{SE}$ ), in the freshwater plume (1 to $5 \mathrm{~m}$ depth) after the breakup of ice in the Kapisigdlit River (20 June), and in subsequent $50 \mathrm{~m}$ strata; $\mathrm{n}=$ number of samples, BD = below detection level

\begin{tabular}{|lccccc|}
\hline Strata (n) & $\mathrm{NO}_{3}$ & $\mathrm{SiO}$ & $\mathrm{PO}_{4}$ & $\mathrm{NO}_{2}$ & $\mathrm{NH}_{3}$ \\
\hline Plume (20) & $\mathrm{BD}$ & $5.09 \pm 0.36$ & $0.038 \pm 0.003$ & $\mathrm{BD}$ & $0.20 \pm 0.002$ \\
$0-50 \mathrm{~m} \mathrm{(47)}$ & $1.70 \pm 0.05$ & $2.07 \pm 0.03$ & $0.22 \pm 0.01$ & $0.03 \pm 0.001$ & $1.12 \pm 0.02$ \\
$50-100 \mathrm{~m}(30)$ & $4.67 \pm 0.10$ & $3.15 \pm 0.07$ & $0.47 \pm 0.01$ & $0.129 \pm 0.003$ & $1.28 \pm 0.03$ \\
$100-150 \mathrm{~m}(16)$ & $5.92 \pm 1.50$ & $5.92 \pm 0.99$ & $0.56 \pm 0.08$ & $0.18 \pm 0.08$ & $1.36 \pm 0.50$ \\
$150-200 \mathrm{~m}(17)$ & $7.21 \pm 1.25$ & $4.43 \pm 0.98$ & $0.65 \pm 0.08$ & $0.24 \pm 0.05$ & $2.02 \pm 1.16$ \\
$>200 \mathrm{~m} \mathrm{(18)}$ & $11.47 \pm 1.23$ & $7.31 \pm 0.58$ & $0.94 \pm 0.14$ & $0.05 \pm 0.03$ & $0.68 \pm 0.39$ \\
\hline
\end{tabular}



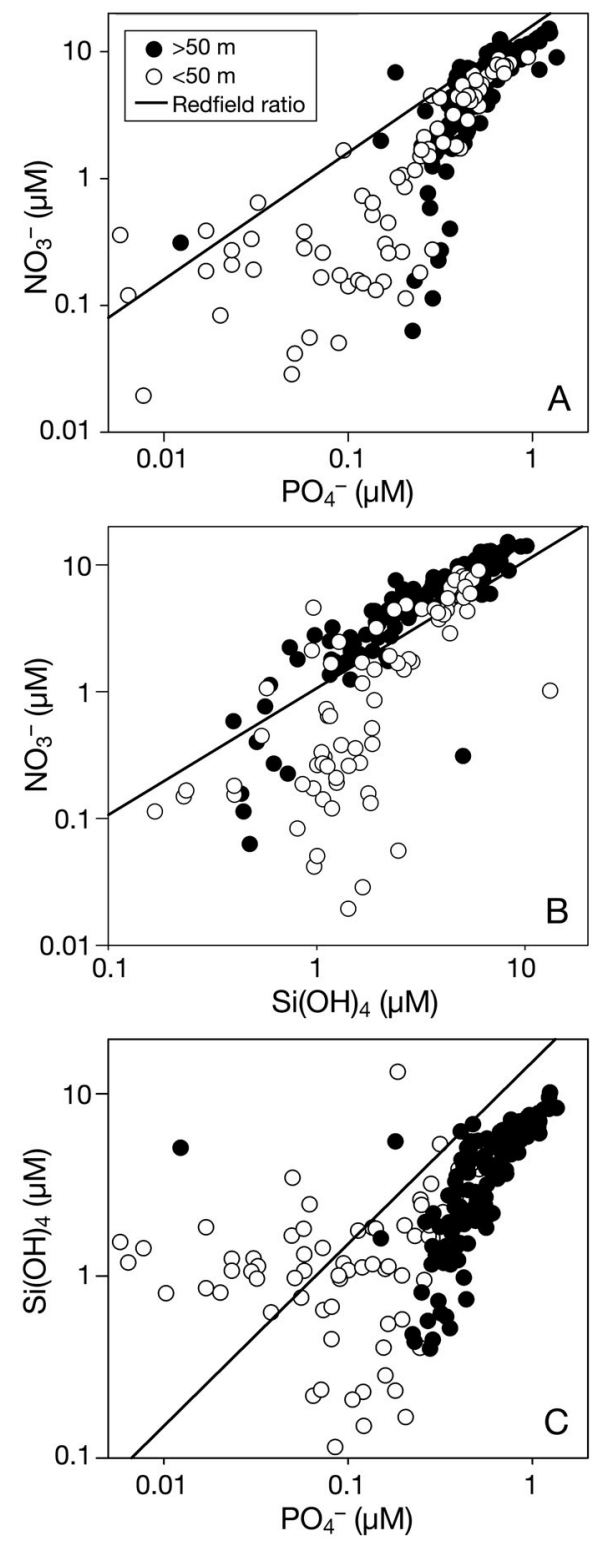

Fig. 3. Relationship between (A) phosphorus and nitrate, (B) silicate and nitrate and (C) phosphorus and silicate. $\bullet=$ samples taken below the euphotic zone (i.e. deeper than $50 \mathrm{~m}$ ); $\mathrm{O}=$ surface samples taken above $50 \mathrm{~m}$. Data from the freshwater plume after the breakup of ice in the river is not included, but shown in Table 4. Lines indicate the RedfieldBrzezinski ratios of the nutrients

freshwater plume overlaid the fjord water, characterized by a very high concentration of silicate (Table 4).

Comparisons of the major nutrient types (Fig. 3AC) suggest nitrate limitation of the primary producers, since nitrate concentration in the upper $50 \mathrm{~m}$ became depleted relative to the Redfield-Brzezinski nutrient ratios with respect to phosphorus (Fig. 3A) and silicate (Fig. 3B).

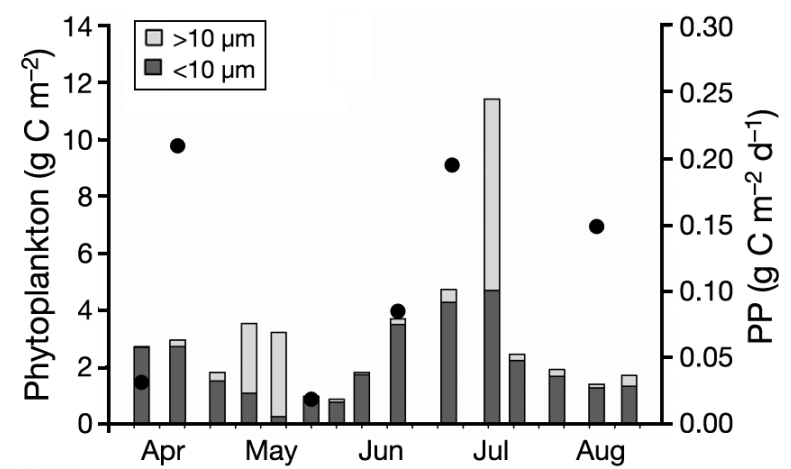

Fig. 4. Seasonal succession in phytoplankton. Bars = integrated biomass, phytoplankton $\left(\mathrm{g} \mathrm{C} \mathrm{m}^{-2}\right) ; \bullet=$ integrated primary production, PP ( $\left.\mathrm{g} \mathrm{C} \mathrm{m}^{-2} \mathrm{~d}^{-1}\right)$. Integration depth: $250 \mathrm{~m}$ for phytoplankton and $45 \mathrm{~m}$ for PP

\section{Phytoplankton}

The integrated phytoplankton biomass averaged $3.0 \pm 2.4 \mathrm{~g} \mathrm{C} \mathrm{m}^{-2}$ over the study period with peak values of 3.5 and $11.4 \mathrm{~g} \mathrm{C} \mathrm{m}^{-2}$ during the spring and summer blooms, respectively (Fig. 4). The phytoplankton spring bloom was initially composed of small phytoplankton cells $(<10 \mu \mathrm{m})$, which progressed into a phase dominated by larger cells $(>10 \mu \mathrm{m})$. Within a few weeks, nitrate was depleted in the euphotic zone, and the total phytoplankton biomass and relative proportion of large phytoplankton cells decreased. As the ice in the Kapisigdlit River broke up in mid-June, a freshwater plume resulted in a temporary upwelling of nutrients into the euphotic zone (Fig. 2), causing a summer bloom to form and the relative proportion of large cells to increase. Nutrients once again became depleted in the stratified water column and the relative proportion of small cells increased (Fig. 4).

Average integrated primary production (PP) for the investigated period was $0.11 \mathrm{~g} \mathrm{C} \mathrm{m}^{-2} \mathrm{~d}^{-1}(\mathrm{n}=6)$ with a maximum of $0.21 \mathrm{~g} \mathrm{C} \mathrm{m}^{-2} \mathrm{~d}^{-1}$ in early spring (Fig. 4). The phytoplankton community was dominated by chain-forming diatoms (mainly Thalassiosira spp.) during the 2 blooms. In the non-bloom periods, the phytoplankton biomass was mostly composed of small $(<10 \mu \mathrm{m})$ unidentified flagellates, primarily cryptophytes and solitary haptophytes (probably Phaeocystis).

\section{Protozooplankton}

At the onset of the investigation, the abundance of protozooplankton was low $\left(<10^{3}\right.$ cells $\left.\mathrm{l}^{-1}\right)$, but throughout June and July a diverse protozooplankton community developed in the upper $50 \mathrm{~m}$, with cell concentrations as high as $3 \times 10^{4}$ cells $\mathrm{l}^{-1}$ 

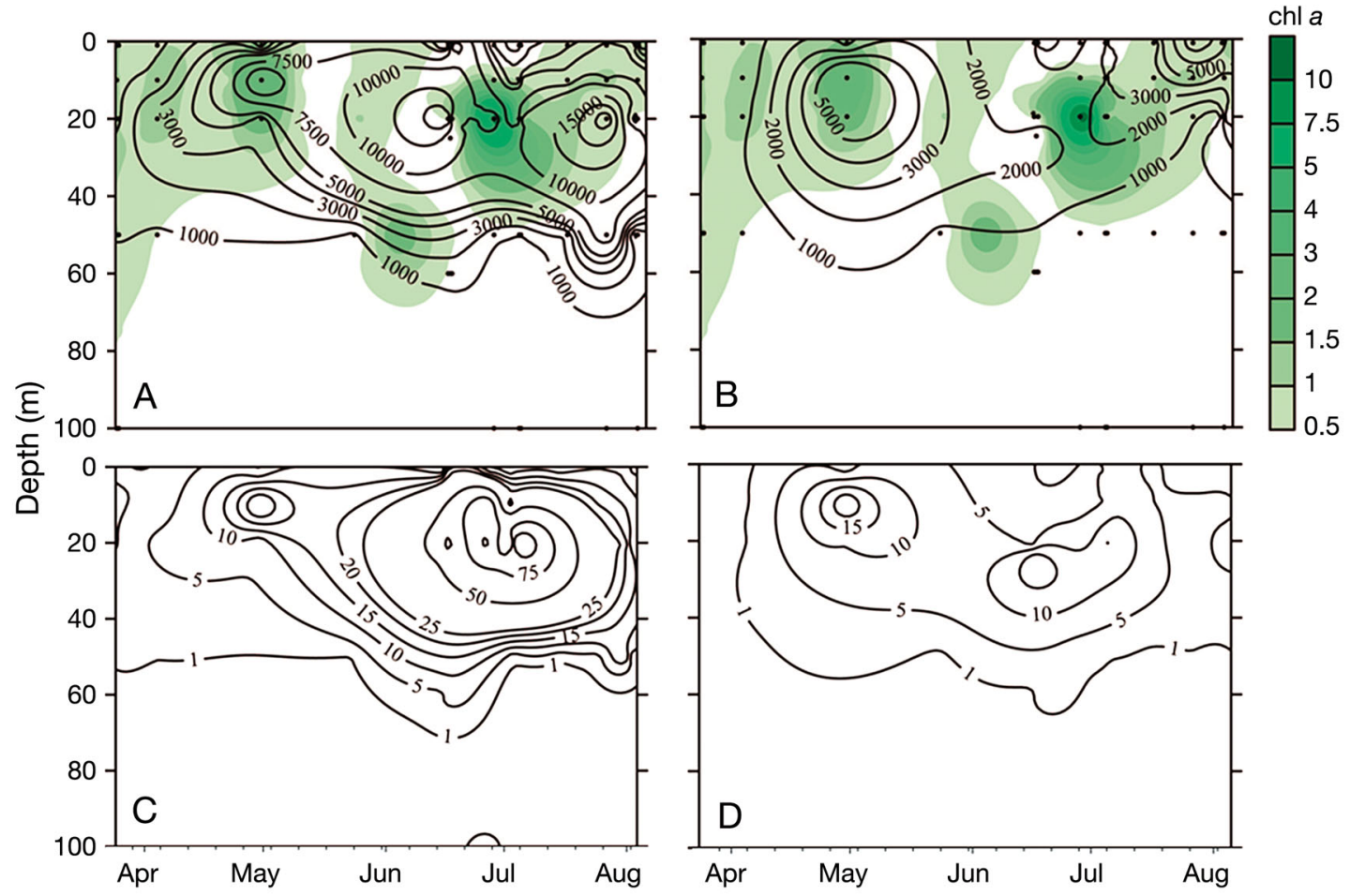

Fig. 5. Seasonal development in the abundance (cells $\mathrm{l}^{-1}$ ) of (A) ciliates and (B) heterotrophic dinoflagellates superimposed on the chl a concentration (green shading, $\mu g \mathrm{l}^{-1}$ ) and $(\mathrm{C}, \mathrm{D})$ seasonal succession in the biomass $\left(\mu \mathrm{g} \mathrm{C} \mathrm{l}^{-1}\right)$ of $(\mathrm{C})$ ciliates and (D) heterotrophic dinoflagellates. Points represent sampling depths

(Fig. 5A,B). Ciliates dominated the protozooplankton community (Fig. 5A), while dinoflagellates were less abundant (Fig. 5B). The protozooplankton biomass mirrored the phytoplankton biomass with maximum biomass associated with the chl a maximum at a depth of $19 \pm 3 \mathrm{~m}$ (mean $\pm \mathrm{SD}$ ). Protozooplankton biomass peaked on July 6 at $155 \mu \mathrm{C} \mathrm{Cl}^{-1}$ (Fig. 5C,D).

The main contributors to the protozooplankton biomass were Strombidium spp. and Gyrodinium spirale during spring, while Mesodinium spp., Strobilidium spp., Strombidium spp., Laboea strobila and G. spirale dominated during the summer (Fig. 6). Numerically, small $(<20 \mu \mathrm{m})$ ciliates dominated the protozooplankton community (Fig. 6).

The integrated biomass of protozooplankton ranged between 0.1 and $4.0 \mathrm{~g} \mathrm{C} \mathrm{m}^{-2}$ (Figs. 7A,B \& 8A). Initially, and by the termination of the investigated period, the protozooplankton community was composed of small ciliates and dinoflagellates. However, during the bloom period, the relative amount of large cells increased. Thus, in June, 45 to $98 \%$ of the integrated protozooplankton biomass was composed of large $(>40 \mu \mathrm{m})$ specimens (mainly ciliates; Fig. 7A).

The estimated protozooplankton production ranged between 0.01 and $0.42 \mathrm{~g} \mathrm{C} \mathrm{m}^{-2} \mathrm{~d}^{-1}$ (Fig. 7C,D). For ciliates, the seasonal variation mirrored the integrated biomass, with small ciliates being the most productive during spring and large ciliates being most productive during the summer (Fig. 7C).

Assuming that ciliates only feed on phytoplankton $<10 \mu \mathrm{m}$, and dinoflagellates only feed on phytoplankton $>10 \mu \mathrm{m}$ (Hansen et al. 1994), the protozooplankton maximum potential ingestion rates ranged between 0.01 and $1.2 \mathrm{~g} \mathrm{C} \mathrm{m}^{-2} \mathrm{~d}^{-1}$, corresponding to 26 to $196 \%$ of the primary production $\mathrm{d}^{-1}$ (data not shown) or 0.5 to $50 \%$ of phytoplankton biomass $\mathrm{d}^{-1}$ (Fig. 7E,F). The highest maximum potential ingestion rates were achieved in the summer after the disappearance of the copepod Metridia longa.

\section{Copepod succession}

The copepod community was dominated by the genera Calanus, Pseudocalanus, Oithona, Microsetella and Triconia/Oncaea. Metridia longa accounted for 72 to $93 \%$ of the copepod biomass in the spring. The integrated biomass of copepods showed a maximum of $24 \mathrm{~g} \mathrm{C} \mathrm{m}^{-2}$ in early March (Fig. 8B), but decreased after 3 June when the community changed towards dominance by smaller species such as Pseudocalanus spp., Microsetella norvegica and Oithona similis. The copepod biomass remained low $\left(<6 \mathrm{~g} \mathrm{C} \mathrm{m}^{-2}\right)$ throughout the rest of the study period. 


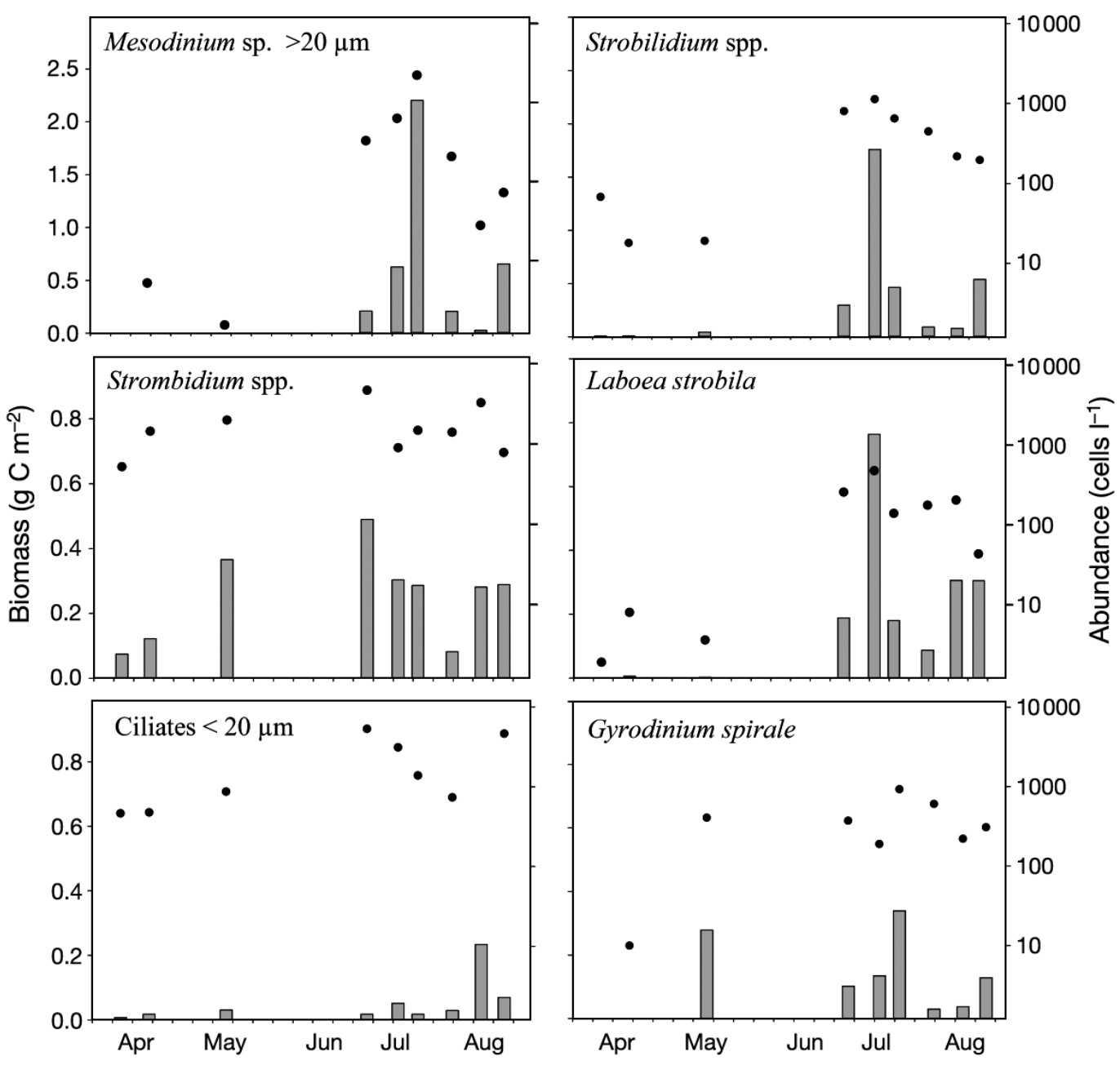

Fig. 6. Seasonal development in selected protozooplankton specimens. Bars $=$ integrated biomass $\left(\mathrm{g} \mathrm{C} \mathrm{m}^{-2}\right) ; \bullet=$ abundance $\left(\right.$ cells $\mathrm{l}^{-1}$ ). Integration depth: $100 \mathrm{~m}$. Note different $y$-axis scales

A pairwise correlation between the integrated protozooplankton biomass and the grazing part of the copepod biomass (i.e. Acartia spp., Calanus spp., Metridia longa, Microcalanus spp., Oithona spp. and Pseudocalanus spp.) revealed a significant relationship between the 2 zooplankton groups, with protozooplankton biomass being inversely proportional to copepod biomass $\left(r^{2}=0.89, p<0.01\right.$; Fig. 9). A similar trend was found between $\mathrm{chl} a$ and copepod biomass $\left(\mathrm{r}^{2}=0.22, \mathrm{p}=0.08\right.$; Fig. 9). No significant correlation was found between protozooplankton biomass and chl a.

\section{Grazing impact by Metridia longa}

The Metridia longa grazing experiment was initiated with a phytoplankton biomass of $22 \mu \mathrm{g} \mathrm{C} \mathrm{l}^{-1}$. Phytoplankton cells in the small size fraction $(0.7$ to
$10 \mu \mathrm{m})$ contributed $95 \%$ of the total phytoplankton biomass. $M$. longa clearance rate on the large $\mathrm{chl}$ a fraction $(>10 \mu \mathrm{m})$ was estimated at $2.1 \pm 0.5 \mathrm{ml} \mu \mathrm{g} \mathrm{C} \mathrm{C}^{-1}$ $\mathrm{d}^{-1}$ (mean $\pm \mathrm{SE}, \mathrm{n}=23$ ), while there was negative clearance $\left(-1.5 \pm 0.6 \mathrm{ml} \mu \mathrm{g} \mathrm{C} \mathrm{C}^{-1} \mathrm{~d}^{-1}\right.$, mean $\pm \mathrm{SE}, \mathrm{n}=$ $23)$ on the small chl a fraction $(<10 \mu \mathrm{m})$. The lower threshold of clearance was corroborated from the Lugol's sample counts, where no significant clearance was found on particles in the size range 3 to $6 \mu \mathrm{m}$ (Fig. 10; $t$-test, $\mathrm{p}>0.05$ ). We cannot conclude whether $M$. longa in fact consumed these small sized prey items or if the non-significant clearance rates on small sized particles are due to a bottle-generated cascade effect caused by removal of protozooplankton in the experimental bottles. This condition may have caused a significant underestimation of the grazing rates (Nejstgaard et al. 1997, 2001). On a global average, copepod grazing on phytoplankton is underestimated by 20 to $30 \%$ in this kind of grazing 

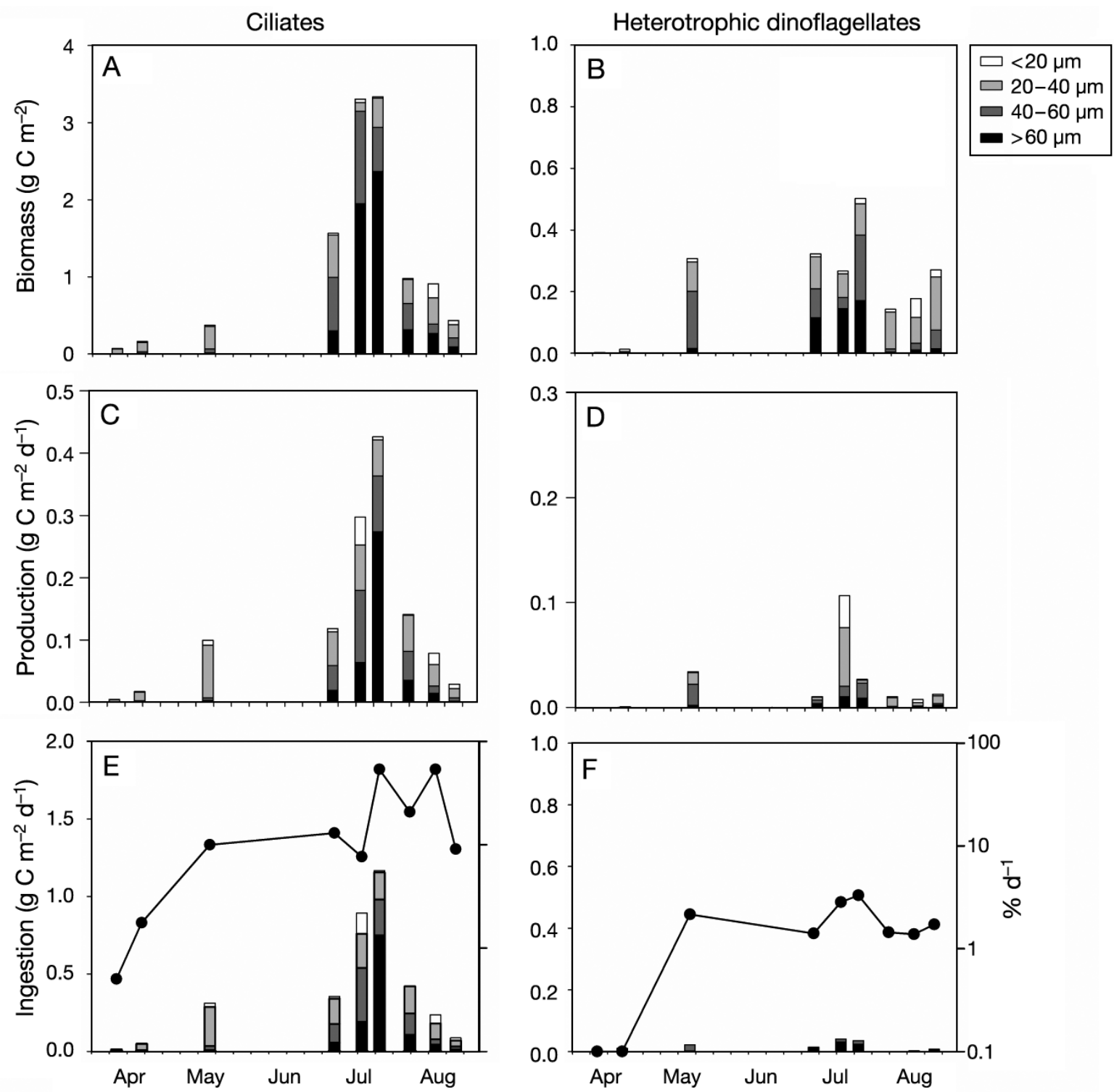

Fig. 7. $(\mathrm{A}, \mathrm{B})$ Integrated biomass $\left(\mathrm{g} \mathrm{C} \mathrm{m}^{-2}\right),(\mathrm{C}, \mathrm{D})$ estimated production $\left(\mathrm{g} \mathrm{C} \mathrm{m}^{-2} \mathrm{~d}^{-1}\right)$ calculated from (E,F) estimated maximal potential ingestion rates $\left(\mathrm{g} \mathrm{C} \mathrm{m}^{-2} \mathrm{~d}^{-1}\right)$ of ciliates and heterotrophic dinoflagellates. The color codes represent the fraction of each protozooplankton size class. Size is given in equatorial spherical diameter (ESD). (E,F) $\bullet=$ phytoplankton biomass ingested per day $\left(\% \mathrm{~d}^{-1}\right)$. Integration depth: $100 \mathrm{~m}$. Note different $y$-axis scales

experiment (Saiz \& Calbet 2011). The protozooplankton concentration in the experimental bottles was $21 \pm 5 \times 10^{3} \mathrm{l}^{-1}$, corresponding to an average biomass of $14 \pm 2 \mu \mathrm{g} \mathrm{C} \mathrm{l}^{-1}$. The protozooplankton community was dominated by Mesodinium spp., Strombidium spp., Gyrodinium spirale, Laboea strobila and Strobilidium oviformis. $M$. longa cleared cells in the size range of 10 to $60 \mu \mathrm{m}$, with an average clearance rate of $2.4 \pm 0.2 \mathrm{ml} \mu \mathrm{g} \mathrm{C}^{-1} \mathrm{~d}^{-1}$ (mean $\pm \mathrm{SE}, \mathrm{n}=26$ ) (Fig. 10A). While clearance rate was positively correlated to prey size $\left(r^{2}=0.90, p=0.06\right)$, no clear relationship was found between biomass of the prey size classes and the clearance rate (Fig. 10B).

\section{Copepod community grazing}

The maximum potential grazing rates of the copepod community was highest from March to late May, when the copepod community cleared $16 \pm 7 \%$ of the water column per day. Metridia longa alone accounted for $>90 \%$ of the maximum potential copepod community clearance (Fig. 11A).

As the Metridia longa population disappeared from the water column, the maximum potential clearance capacity was reduced, and remained low $\left(7 \pm 2 \%\right.$ water column $\left.\mathrm{d}^{-1}\right)$ throughout the summer period (Fig. 11A). Generally, our maximum poten- 

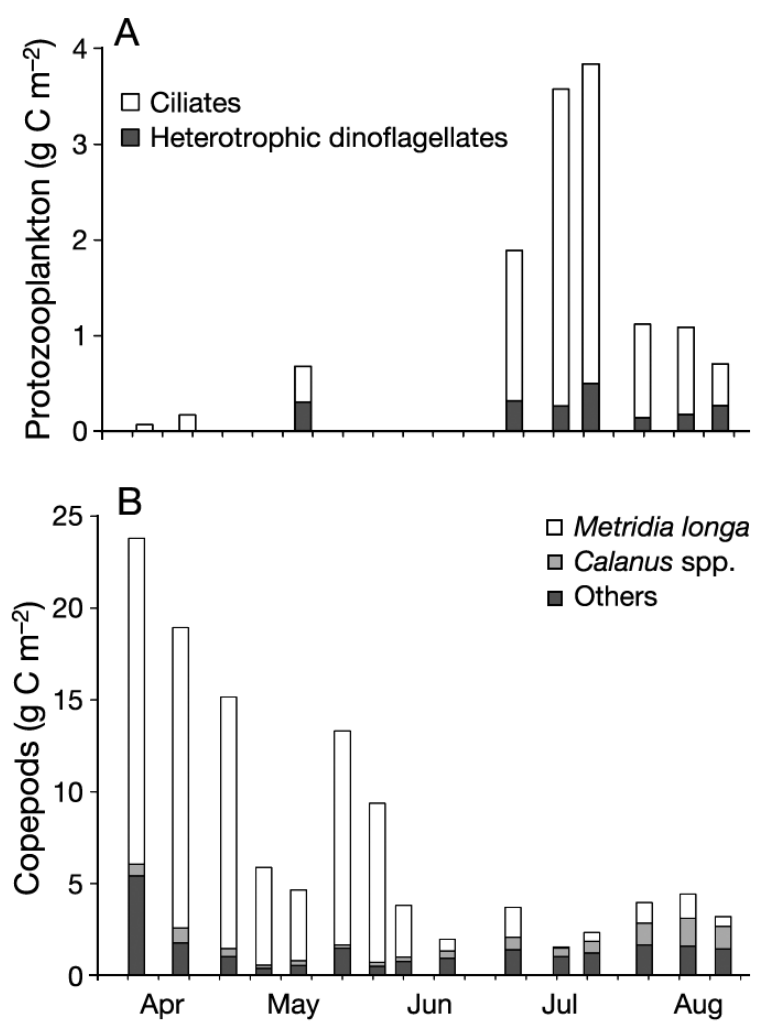

Fig. 8. (A) Integrated protozooplankton biomass $\left(\mathrm{g} \mathrm{C} \mathrm{m}^{-2}\right)$, (B) integrated copepod biomass $\left(\mathrm{g} \mathrm{C} \mathrm{m}^{-2}\right)$. Integration depth: $100 \mathrm{~m}$ for protozooplankton and $250 \mathrm{~m}$ for copepod biomass

tial grazing estimates suggest that $M$. longa was able to control the protozooplankton community during spring, grazing $>100 \%$ of the protozooplankton production every day (Fig. 11B). From June to August, the predation pressure declined and there was an intense buildup of protozooplankton biomass in response to the reduction in $M$. longa grazing pressure.

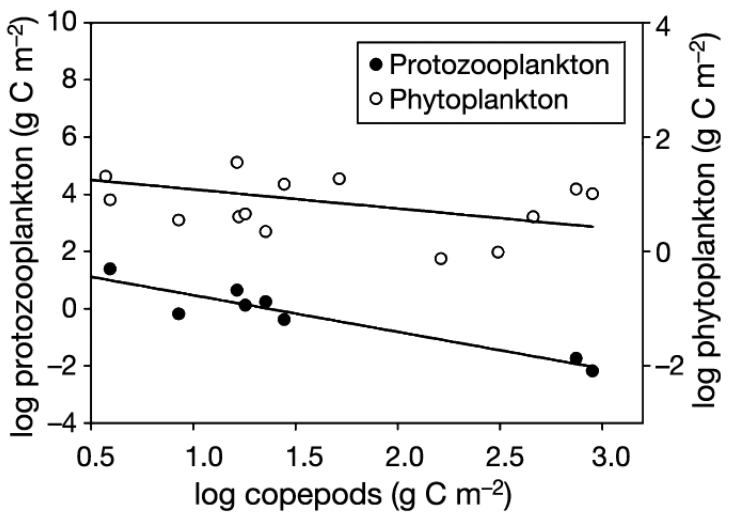

Fig. 9. Relationship between integrated copepod biomass and integrated phytoplankton and protozooplankton biomass. White dots indicate regression between copepods and phytoplankton $\left(\mathrm{r}^{2}=0.22, \mathrm{p}=0.08\right)$. Black dots indicate regression between copepods and protozooplankton $\left(r^{2}=0.89\right.$, $\mathrm{p}<0.01)$

\section{DISCUSSION}

\section{Hydrography and plankton characteristics}

Fjords are important environments of the coastal zone of Greenland. They are the first components of the marine regime to be impacted by increased melt water from land, and are therefore suitable proxies to determine how open marine environments may respond in a warmer future. In this sense, the freshwater-impacted Kapisigdlit Fjord branch represents an ideal test site to develop an understanding of the potential impact of increased freshwater input and water-column stratification on the pelagic community.

The Kapisigdlit Fjord is a seasonally oligotrophic, stratified subarctic ecosystem controlled by nitrate during the productive season. The fjord shows strong seasonality in chl a concentrations, but is character-
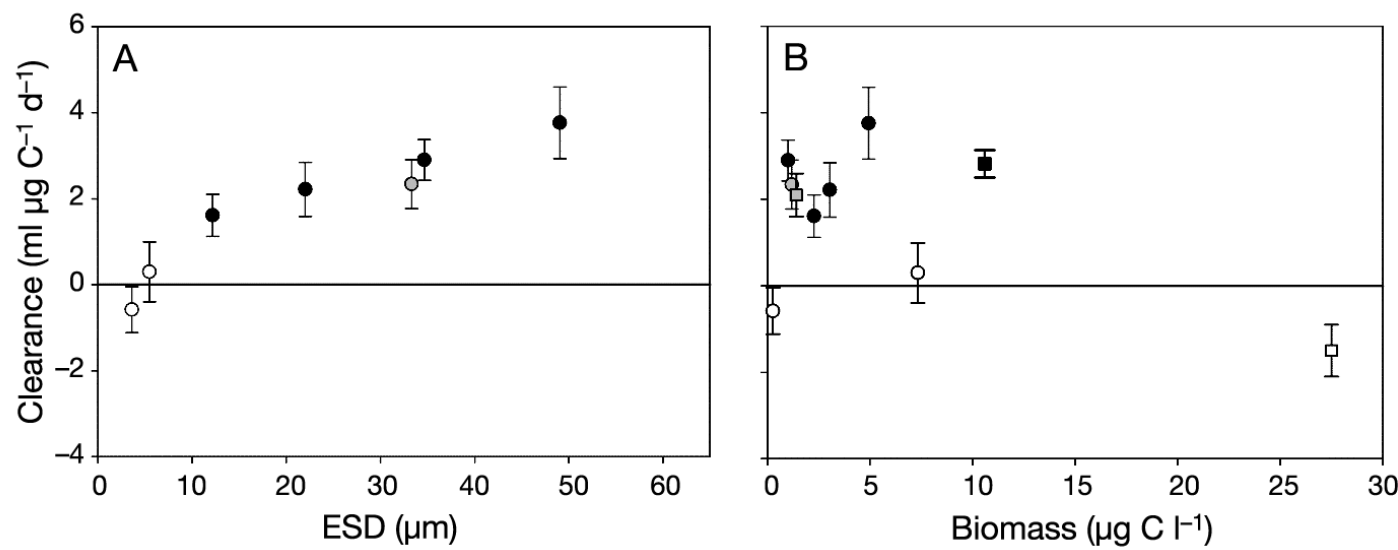

- Ciliates

- Dinoflagellates - Nanoflagellates

口 Phytoplankton $<10 \mu \mathrm{m}$

$\square$ Phytoplankton $>10 \mu \mathrm{m}$

- Protozooplankton $>10 \mu \mathrm{m}$

Fig. 10. Metridia longa. Specific clearance rate $\left(\mathrm{ml} \mu \mathrm{g} \mathrm{C} \mathrm{C}^{-1} \mathrm{~d}^{-1}\right)$ at $3^{\circ} \mathrm{C}$ of different (A) size classes and (B) biomass classes of ciliates, dinoflagellates, nanoflagellates and phytoplankton. ESD: equatorial spherical diameter. Error bars indicate mean \pm SE $(n=23)$ 

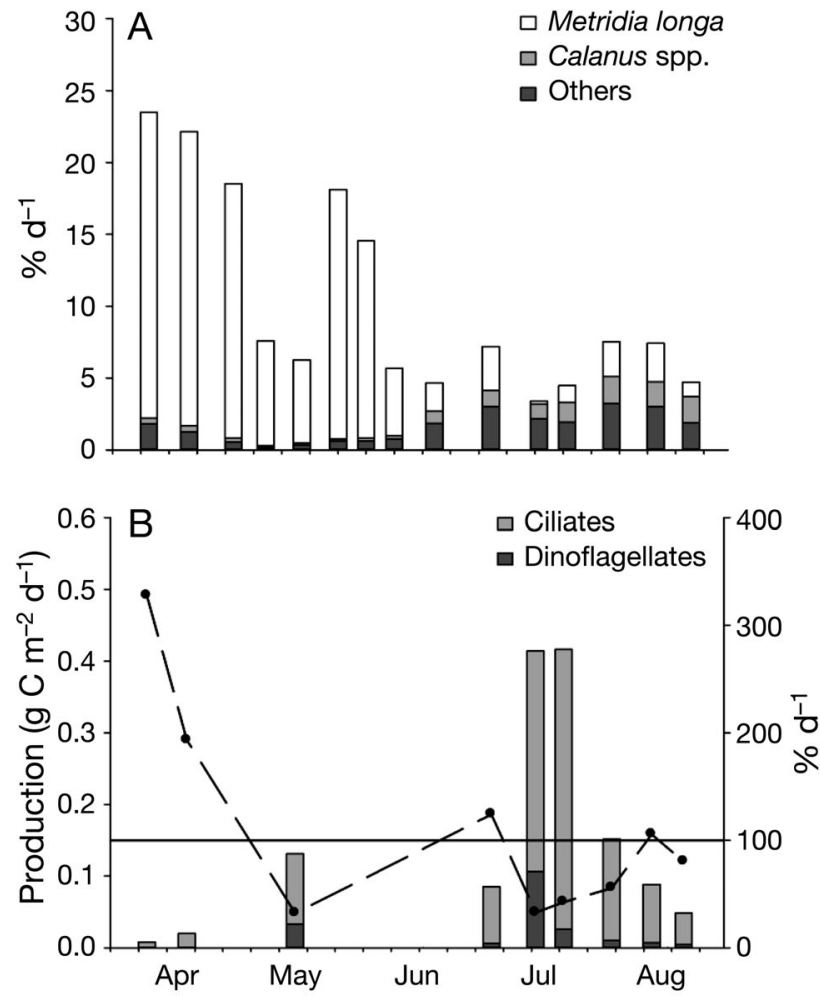

Fig. 11. Seasonal development in copepod grazing impact. (A) Water column cleared for cells in the size range 10 to $60 \mu \mathrm{m}$ by the copepod community $\left(\% \mathrm{~d}^{-1}\right)$; (B) bars = integrated protozooplankton production $\left(\mathrm{g} \mathrm{C} \mathrm{m}^{-2} \mathrm{~d}^{-1}\right)$ and $\bullet=$ fraction of protozooplankton production cleared by the copepod community $\left(\% \mathrm{~d}^{-1}\right)$. 'Others' represent copepods dominated by Pseudocalanus spp., Oithona spp., Centropages spp. and Microcalanus spp.

ized by lower concentrations than reported from other subarctic and Arctic regions, where the surface chl a generally exceeds $1.5 \mathrm{\mu g} \mathrm{l}^{-1}$ during the productive season (Pabi et al. 2008). The freshwater runoff in the Kapisigdlit Fjord creates a more stratified water column-which prevents mixing of nutrients upward into the euphotic zone, as shown by the low chl a concentrations, the low primary production rates and the high proportions of nanophytoplankton and protozooplankton.

Few attempts have been made to investigate the role of protozooplankton in subarctic and Arctic ecosystems, and most studies have focused on the highproductive regions dominated by diatoms and Calanus spp. (Verity et al. 2002, Sherr \& Sherr 2007, Seuthe et al. 2011). This research documented that subarctic fjords may support rich and diverse protozooplankton communities, and that their abundances are comparable to levels found in temperate waters (Sherr \& Sherr 2007, Saiz \& Calbet 2011).

Compared to existing data from subarctic and Arctic regions, the protozooplankton biomass in the
Godthåbsfjord (including Kapisigdlit Fjord) is remarkably high (Poulsen \& Reuss 2002, Arendt et al. 2010, this study). Maximum integrated protozooplankton biomasses in coastal Arctic and subarctic waters such as Kongsfjorden (Svalbard), Disko Bay (West Greenland), Young Sound (Northeast Greenland), Fyllas Banke (off West Greenland), the Barents Sea and the subarctic Pacific Ocean have been reported in the range 0.2 to $1.7 \mathrm{~g} \mathrm{C} \mathrm{m}^{-2}$ (Strom et al. 1993, Rysgaard et al. 1999, Levinsen et al. 2000, Rat'kova \& Wassmann 2002, Seuthe et al. 2011). In comparison, the maximum integrated protozooplankton biomass in the Kapisigdlit Fjord was $4.0 \mathrm{~g} \mathrm{C} \mathrm{m}^{-2}$.

In contrast to studies at Fyllas Banke, Kongsfjorden, Disko Bay and Young Sound, where dinoflagellates dominated the protozooplankton community (Levinsen \& Nielsen 2002, Poulsen \& Reuss 2002, Sherr et al. 2009, Seuthe et al. 2011), ciliates contributed $82 \%$ of the total protozooplankton biomass in our study. A similar community structure has been observed in the Barents Sea (Rat'kova \& Wassmann 2002) and in the subarctic Pacific Ocean (Strom et al. 1993). The difference in the relative composition of the protozooplankton community can be explained by the different feeding strategies of ciliates and dinoflagellates. While ciliates generally prefer small particles $(\sim 2$ to $10 \mu \mathrm{m})$, heterotrophic dinoflagellates feed on diatoms and other large particles $(>10 \mu \mathrm{m})$ (Hansen et al. 1994). The Kapisigdlit Fjord represents a seasonally stratified and oligotrophic ecosystem supporting a phytoplankton community of small flagellates, and accordingly, ciliates as the dominant protozooplankton grazers. Ciliates feeding on nanoflagellates could not be distinguished from potential predatory ciliates feeding on other ciliates and dinoflagellates. However, predatory ciliates such as Didinium spp. or Favella ehrenbergii (Berger 1980, Stoecker et al. 1981) were rare in the samples, and thus predatory ciliates were not considered important for the trophic role of the protozooplankton community.

The estimated maximum potential grazing impact of protozooplankton on phytoplankton was highly variable, but generally exceeded $100 \%$ of the primary production during the summer months. This high grazing impact of protozooplankton is consistent with data from Calbet et al. (2011) who, based on dilution experiments, estimated grazing rates corresponding to $128 \%$ of the primary production consumed per day in June. In comparison, grazing rates estimated from dilution experiments in other regions of Arctic seas have been in the range of 26 to $77 \%$ of the primary production per day (Verity et al. 2002, Sherr et al. 2009). Although the maximum potential 
grazing impact may be slightly overestimated due to inclusion of mixotrophic species such as Mesodinium rubrum, Laboea strobila and Strombidium cornicum, the results emphasize the need to consider protozooplankton as key grazers in high latitude ecosystems.

\section{Protozooplankton as prey for copepods}

It is well documented that Calanus can exploit protozooplankton (Ohman \& Runge 1994, Levinsen et al. 2000, Turner et al. 2001). Knowledge of Metridia feeding biology indicates this species consumes diatoms, nauplii and copepod eggs (Haq 1967, Sell et al. 2001, Campbell et al. 2009, Kjellerup \& Kiørboe 2012). In contrast to typical suspension-feeding copepods (e.g. Calanus) which generate a feeding current to capture prey, Metridia longa feeds by cruising through the water, capturing prey by remote detection (Kjellerup \& Kiørboe 2012). The cruising behavior of Metridia may be an advantage in environments in which prey concentrations are low, or when the prey tries to escape the feeding current (e.g. ciliates such as Mesodinium rubrum; Jonsson \& Tiselius 1990, Fenchel \& Hansen 2006). Haq (1967) demonstrated that M. longa was able to capture prey in the size range 5 to 300 $\mu \mathrm{m}$, with clearance rates in the range of 3 to $7 \mathrm{ml}$ ind. ${ }^{-1}$ $\mathrm{d}^{-1}$. Our study indicates that particles $<60 \mu \mathrm{m}$ are efficiently consumed by adult $M$. longa females, but in comparison to Haq (1967), the average clearance rate was higher: $222 \pm 36 \mathrm{ml}$ ind. ${ }^{-1} \mathrm{~d}^{-1}$ (mean $\pm \mathrm{SE}, \mathrm{n}=26$ ) for protozooplankton in the size range 10 to $60 \mu \mathrm{m}$. The estimated grazing rates obtained from the grazing experiment are close to maximum potential clearance rates estimated from empirical relations in Hansen et al. (1997, 2000) and Møller et al. (2006) (Fig. 12). The low clearance rates presented in Haq (1967) could be explained by the limited variability in offered prey, since $M$. longa was only exposed to phytoplankton cells, small flagellates and Artemia nauplii. Our data suggest that $M$. longa has a high affinity for protozooplankton prey. Similarly, Haq (1967) demonstrated that $M$. longa feed more rapidly on animal prey than on phytoplankton. Due to the size composition of the plankton community and the possible cascading effects within the phytoplankton community in the grazing experiment, we did not find upper and lower prey size thresholds for M. longa. However, the relative optimal size range of prey for copepods is surprisingly constant between species, suggesting that adult copepods of similar size to $M$. longa have an optimal prey size range of $\sim 10$ to $70 \mu \mathrm{m}$ (Berggreen et al. 1988, Hansen et al. 1994, Levinsen et al. 2000).

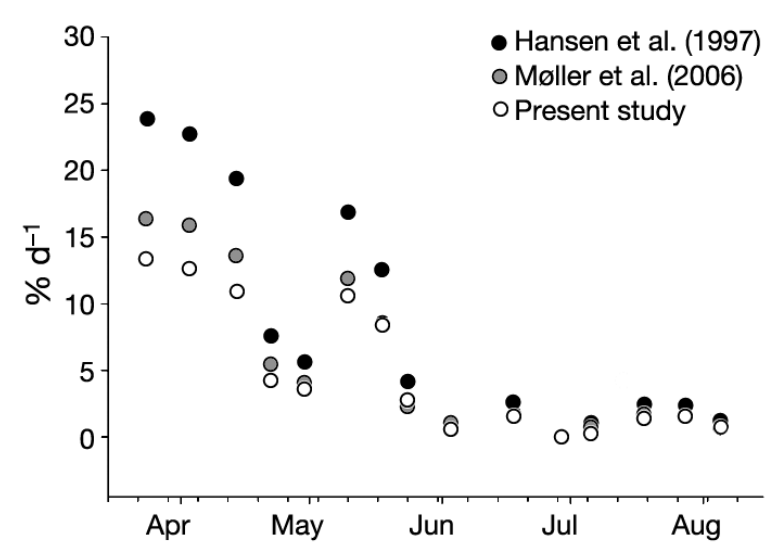

Fig. 12. Water column cleared for cells in the size range 10 to $60 \mu \mathrm{m}$ by Metridia longa $\left(\% \mathrm{~d}^{-1}\right)$. Values are estimated using maximum potential clearance rates from Hansen et al. (1997) and Møller et al. (2006), or by using the average clearance rate generated from the grazing experiment with $M$. longa (present study)

Since the in situ size composition of the phytoplankton in the Kapisigdlit Fjord was dominated by small cells $(<10 \mu \mathrm{m})$, we presume that only a small fraction of the phytoplankton community is available to adult Metridia longa, and that survival of this species to a large extent is dependent on prey items such as microzooplankton. During the study period, ciliates and dinoflagellates accounted for $55 \%$ $(10-81 \%)$ and $10 \%(2-25 \%)$ respectively, of the carbon available for the copepods, assuming that copepods primarily feed on phytoplankton and protozooplankton $>10 \mu \mathrm{m}$. This proportion is within the same magnitude as found in global oligotrophic ecosystems $\left(<50 \mu \mathrm{g} \mathrm{Cl}^{-1}\right)$, where ciliates and dinoflagellates on average account for 43 and $19 \%$ of the copepod carbon consumption, respectively (Saiz \& Calbet 2011). Although M. longa is known to consume nauplii (Haq 1967, Kjellerup \& Kiørboe 2012), nauplii only contributed $11 \%(1-40 \%)$ of the microzooplankton biomass (calculated as the sum of ciliate, dinoflagellate and nauplii biomass). Prey preference and clearance rate will likely vary depending on the copepod community composition and prey availability. However, throughout the study period, adult females and copepodites in the CV stage constituted $78 \pm 9 \%(55-89 \%)$ of the entire $M$. longa biomass (i.e. all copepod stages including nauplii, copepodites and males), indicating that the rates estimated from our grazing experiment are within a realistic range. Thus, the present study indicates that protozooplankton, especially ciliates, are an essential source of food for the copepod community in subarctic oligotrophic systems, such as the Kapisigdlit Fjord. 


\section{Correcting grazing impact to in situ temperature using $Q_{10}$}

The in situ temperature throughout the study period ranged between 0.5 and $13^{\circ} \mathrm{C}$. Literature $Q_{10}$ values for maximum potential clearance, ingestion and production rates of protozooplankton and copepods (reviewed in Hansen et al. 1997) range between 1.5 and 4.0 (average 2.8) within the temperature range 5 to $25^{\circ} \mathrm{C}$. Since there are no consistent differences in $Q_{10}$ between temperatures, a universal $Q_{10}$ of 2.8 was applied to all temperatures when estimating maximum grazing potential. By using $Q_{10}$ within the range of 1.5 to 4.0 , the overall conclusions of the study would be unchanged. For example, using a $Q_{10}$ of 4.0 at temperatures $<5^{\circ} \mathrm{C}$, maximum potential clearance, ingestion and production rates for protozooplankton would have been $28 \%$ lower than when using a $Q_{10}$ of 2.8 for all temperatures.

\section{Regulation of protozooplankton}

The late summer peak of protozooplankton observed in the Kapisigdlit Fjord is a result of the disappearance of large copepods, a condition that reduces the grazing pressure on the protozooplankton community. A similar seasonal succession has been observed in Disko Bay (Levinsen \& Nielsen 2002), where a 'regulation window' is created by the phytoplankton spring bloom. During the spring bloom, Calanus becomes food-saturated and thereby decreases the grazing pressure on the protozooplankton. In Disko Bay, a second 'window' is created when the adult Calanus leave the surface layer in the late summer. In the Kapisigdlit Fjord, the 'regulation window' is established as the predation pressure from Metridia longa is reduced when leaving the surface layer. This 'regulation window' stays 'open' a few weeks during the summer period until a high grazing pressure is reestablished by a late summer community of small copepods; mainly Oithona spp. (Figs. 8 \& 11). In highArctic regions such as Young Sound, 'regulation windows' are usually absent due to the brief open water period. In these systems, copepods are able to consume most of the primary production, meaning that copepods control both the phytoplankton and protozooplankton during the entire productive season (Rysgaard et al. 1999, Nielsen et al. 2007).

Climate changes are probably the largest ecological threats facing the Arctic marine environment in the future. More detailed knowledge about trophic dynamics in subarctic marine ecosystems will pro- vide a basis for predicting the consequences of regime shifts in high latitudes. In some areas of the Arctic, increased temperatures may reduce the seaice cover and expand the productive season (Tremblay \& Gagnon 2009, Slagstad et al. 2011), allowing more complex plankton communities to develop (Rysgaard et al. 1999). Intensified precipitation and glacial melting may strengthen water column stratification, which would favor the development of smallsized phytoplankton populations (Ardyna et al. 2011) and position ciliates as key grazers. According to this scenario, the zooplankton community would change from dominance by copepods towards a more bimodal grazer succession, with a peak of large calanoid copepods in the spring succeeded by a late summer peak of protozooplankton and small copepod species, as illustrated in Disko Bay (Levinsen \& Nielsen 2002) and the present study.

Acknowledgements. The research leading to these results was funded by the European Commission FP7 EUROBASIN (Grant Agreement: 264 933) and the Greenland Climate Research Centre (Project 6505). We acknowledge the marine sub-program of the Greenland Ecosystem Monitoring program for assistance in equipment and primary production estimates. We thank the captains and crew for excellent help during sampling on RVs 'Lille Masik' and 'Dana'. We also thank S. Zamora-Terol, B. Søborg, T. Krogh, K. Kreutzmann, H. Philipsen and J. Mortensen for help with logistics and equipment.

\section{LITERATURE CITED}

Ardyna M, Gosselin M, Michel C, Poulin M, Tremblay J (2011) Environmental forcing of phytoplankton community structure and function in the Canadian High Arctic: contrasting oligotrophic and eutrophic regions. Mar Ecol Prog Ser 442:37-57

Arendt KE, Nielsen TG, Rysgaard S, Tönnesson K (2010) Differences in plankton community structure along the Godthåbsfjord, from the Greenland Ice Sheet to offshore waters. Mar Ecol Prog Ser 401:49-62

Arendt KE, Juul-Pedersen T, Mortensen J, Blicher ME, Rysgaard S (2012) A 5-year study of seasonal patterns in mesozooplankton community structure in a sub-Arctic fjord reveals dominance of Microsetellanorvegica (Crustacea, Copepoda). J Plankton Res 35:105-120

Berger J (1980) Feeding-behavior of Didinium nasutum on Paramecium bursaria with normal or apochlorotic zoochlorellae. J Gen Microbiol 118:397-404

Berggreen U, Hansen B, Kiørboe T (1988) Food size spectra, ingestion and growth of the copepod Acartia tonsa during development: implications for determination of copepod production. Mar Biol 99:341-352

Bergstrøm B, Vilhajalmsson H (2008) Cruise report and preliminary results of the acoustic/pelagic trawl survey off West Greenland for capelin and polar cod 2005. Technical Report No. 66, Greenland Institute of Natural Resources, Nuuk 
Calbet A, Riisgaard K, Saiz E, Zamora S, Stedmon C, Nielsen TG (2011) Phytoplankton growth and microzooplankton grazing along a sub-Arctic fjord (Godthåbsfjord, west Greenland). Mar Ecol Prog Ser 442:11-22

> Campbell RG, Sherr EB, Ashjian CJ, Plourde S, Sherr BF, Hill V, Stockwell DA (2009) Mesozooplankton prey preference and grazing impact in the Western Arctic Ocean. Deep-Sea Res II 56:1274-1289

> Comiso JC, Parkinson CL, Gersten R, Stock L (2008) Accelerated decline in the Arctic sea ice cover. Geophys Res Lett 35:L01703, doi:10.1029/2007GL031972

> Daase M, Eiane K, Aksnes DL, Vogedes D (2008) Vertical distribution of Calanus spp. and Metridia longa at four Arctic locations. Mar Biol Res 4:193-207

> Digby PSB (1953) Plankton production in Scoresby Sound, East Greenland. J Anim Ecol 22:289-322

Falkenhaug T, Tande KS, Semenova T (1997) Diel, seasonal and ontogenetic variations in the vertical distributions of four marine copepods. Mar Ecol Prog Ser 149:105-119

$>$ Fenchel T, Hansen PJ (2006) Motile behaviour of the bloomforming ciliate Mesodinium rubrum. Mar Biol Res 2: 33-40

> Frost BW (1972) Effects of size and concentration of food particles on feeding behavior of marine planktonic copepod Calanus pacificus. Limnol Oceanogr 17:805-815

> Hamilton L, Lyster P, Otterstad O (2000) Social change, ecology and climate in 20th-century Greenland. Clim Change 47:193-211

Hansen PJ (2011) The role of photosynthesis and food uptake for the growth of marine mixotrophic dinoflagellates. J Eukaryot Microbiol 58:203-214

Hansen H, Koroleff F (1999) Determination of nutrients. In: Grasshoff K, Kremling K, Ehrhardt M (eds) Methods of seawater analysis, 3rd edn. Wiley-VCH, Weinheim, p 159-228

> Hansen B, Bjørnsen PK, Hansen PJ (1994) The size ratio between planktonic predators and their prey. Limnol Oceanogr 39:395-403

Hansen PJ, Bjørnsen PK, Hansen BW (1997) Zooplankton grazing and growth: scaling within the $2-2000-\mu \mathrm{m}$ body size range. Limnol Oceanogr 42:687-704

Hansen PJ, Bjørnsen PK, Hansen BW (2000) Zooplankton grazing and growth: Scaling within the 2-2000- $\mu$ m body size range. Limnol Oceanogr 45:1891 [Erratum to Limnol Oceanogr 42:687-704]

> Haq SM (1967) Nutritional physiology of Metridia lucens and M. longa from Gulf of Maine. Limnol Oceanogr 12: 40-51

Hays GC (1995) Ontogenetic and seasonal variation in the diel vertical migration of the copepods Metridia lucens and Metridia longa. Limnol Oceanogr 40:1461-1465

Hirche HJ, Mumm N (1992) Distribution of dominant copepods in the Nansen Basin, Arctic-Ocean, in summer. Deep-Sea Res A 39:S485-S505

> Holland DM, Thomas RH, De Young B, Ribergaard MH, Lyberth B (2008) Acceleration of Jakobshavn Isbræ triggered by warm subsurface ocean waters. Nat Geosci 1:659-664

Hopkins CCE, Tande KS, Grønvik S, Sargent JR (1984) Ecological investigations of the zooplankton community of Balsfjorden, Northern Norway: an analysis of growth and overwintering tactics in relation to niche and environment in Metridia longa (Lubbock), Calanus finmarchicus (Gunnerus), Thysanoessa inermis (Krøyer) and Thysanoessa raschi (M. Sars). J Exp Mar Biol Ecol 82:77-99
Hygum BH, Rey C, Hansen BW, Tande K (2000) Importance of food quantity to structural growth rate and neutral lipid reserves accumulated in Calanus finmarchicus. Mar Biol 136:1057-1073

> Jakobsen HH, Hansen PJ (1997) Prey size selection, grazing and growth response of the small heterotrophic dinoflagellate Gymnodinium sp. and the ciliate Balanion comatum - a comparative study. Mar Ecol Prog Ser 158: 75-86

Jespersen AM, Christoffersen K (1987) Measurements of chlorophyll-a from phytoplankton using ethanol as extraction solvent. Arch Hydrobiol 109:445-454

> Jonsson PR, Tiselius P (1990) Feeding-behavior, prey detection and capture efficiency of the copepod Acartia tonsa feeding on planktonic ciliates. Mar Ecol Prog Ser 60: 35-44

Juul-Pedersen T, Nielsen TG, Michel C, Møller EF and others (2006) Sedimentation following the spring bloom in Disko Bay, West Greenland, with special emphasis on the role of copepods. Mar Ecol Prog Ser 314:239-255

Kjellerup S, Kiørboe T (2012) Prey detection in a cruising copepod. Biol Lett 8:438-441

Klein Breteler WCM, Fransz HG, Gonzalez SR (1982) Growth and development of four calanoid copepod species under experimental and natural conditions. Neth J Sea Res 16:195-207

Koski M, Møller EF, Maar M, Visser AW (2007) The fate of discarded appendicularian houses: degradation by the copepod, Microsetella norvegica, and other agents. J Plankton Res 29:641-654

> Levinsen H, Nielsen TG (2002) The trophic role of marine pelagic ciliates and heterotrophic dinoflagellates in arctic and temperate coastal ecosystems: a cross-latitude comparison. Limnol Oceanogr 47:427-439

> Levinsen H, Turner JT, Nielsen TG, Hansen BW (2000) On the trophic coupling between protists and copepods in arctic marine ecosystems. Mar Ecol Prog Ser 204:65-77

> Madsen SD, Nielsen TG, Hansen BW (2001) Annual population development and production by Calanus finmarchicus, C. glacialis and C. hyperboreus in Disko Bay, western Greenland. Mar Biol 139:75-93

Menden-Deuer S, Lessard EJ (2000) Carbon to volume relationships for dinoflagellates, diatoms, and other protist plankton. Limnol Oceanogr 45:569-579

> Møller EF, Nielsen TG, Richardson K (2006) The zooplankton community in the Greenland Sea: composition and role in carbon turnover. Deep-Sea Res I 53:76-93

> Mortensen J, Lennert K, Bendtsen J, Rysgaard S (2011) Heat sources for glacial melt in a sub-Arctic fjord (Godthåbsfjord) in contact with the Greenland Ice Sheet. J Geophys Res 116:C01013, doi:10.1029/2010JC006528

Motyka RJ, Truffer M, Fahnestock M, Mortensen J, Rysgaard S (2011) Submarine melting of the 1985 Jakobshavn Isbræ floating tongue and the triggering of the current retreat. J Geophys Res 116:F01007, doi:10.1029/ 2009JF001632

Nejstgaard JC, Gismervik I, Solberg PT (1997) Feeding and reproduction by Calanus finmarchicus, and microzooplankton grazing during mesocosm blooms of diatoms and the coccolithophore Emiliania huxleyi. Mar Ecol Prog Ser 147:197-217

Nejstgaard JC, Naustvoll JL, Sazhin A (2001) Correcting for underestimation of microzooplankton grazing in bottle incubation experiments with mesozooplankton. Mar Ecol Prog Ser 221:59-75 
Nielsen TG, Hansen B (1995) Plankton community structure and carbon cycling on the western coast of Greenland during and after the sedimentation of a diatom bloom. Mar Ecol Prog Ser 125:239-257

Nielsen TG, Hansen PJ (1999) Dyreplankton i danske farvande. Danmarks Miljøundersøgelser. TEMA-rapport fra DMU, Miljø- og Energiministeriet, No. 28/1999, Roskilde

Nielsen TG, Ottosen LD, Hansen BW (2007). Structure and function of the pelagic ecosystem in an ice covered arctic fjord. In: Rysgaard S, Glud RN (Eds.) Carbon cycling in Arctic marine ecosystems: case study Young Sound. Meddr Greenland, Bioscience Special Issue p 88-107

$>$ Ohman MD, Runge JA (1994) Sustained fecundity when phytoplankton resources are in short supply: omnivory by Calanus finmarchicus in the Gulf of St. Lawrence. Limnol Oceanogr 39:21-36

Pabi S, van Dijken GL, Arrigo KR (2008) Primary production in the Arctic Ocean, 1998-2006. J Geophys Res 113: C08005, doi:10.1029/2007JC004578

> Pedersen T, Fossheim M (2008) Diet of 0-group stages of capelin (Mallotus villosus), herring (Clupea harengus) and cod (Gadus morhua) during spring and summer in the Barents Sea. Mar Biol 153:1037-1046

Poulsen LK, Reuss N (2002) The plankton community on Sukkertop and Fylla Banks off West Greenland during a spring bloom and post-bloom period: hydrography, phytoplankton and protozooplankton. Ophelia 56:69-85

> Putt M, Stoecker DK (1989) An experimentally determined carbon-volume ratio for marine oligotrichous ciliates from estuarine and coastal waters. Limnol Oceanogr 34: 1097-1103

Rat'kova TN, Wassmann P (2002) Seasonal variation and spatial distribution of phyto- and protozooplankton in the central Barents Sea. J Mar Syst 38:47-75

Rysgaard S, Glud RN (2004) Anaerobic $\mathrm{N}_{2}$ production in Arctic sea ice. Limnol Oceangr 49(1):86-94

Rysgaard S, Nielsen TG, Hansen BW (1999) Seasonal variation in nutrients, pelagic primary production and grazing in a high-Arctic coastal marine ecosystem, Young Sound, Northeast Greenland. Mar Ecol Prog Ser 179:13-25

Sabatini M, Kiørboe T (1994) Egg production, growth and development of cyclopoid copepod Oithona similis. J Plankton Res 16: 1329-1351

Saiz E, Calbet A (2011) Copepod feeding in the ocean: scaling patterns, composition of their diet and the bias of estimates due to microzooplankton grazing during incubations. Hydrobiologia 666:181-196

Satapoomin S (1999) Carbon content of some common tropical Andaman Sea copepods. J Plankton Res 21:21172123

Sell AF, van Keuren D, Madin LP (2001) Predation by omnivorous copepods on early developmental stages of Calanus finmarchicus and Pseudocalanus spp. Limnol Oceanogr 46:953-959

Seuthe L, Iversen KR, Narcy F (2011) Microbial processes in a high-latitude fjord (Kongsfjorden, Svalbard): II. Ciliates and dinoflagellates. Polar Biol 34:751-766

Sherr EB, Sherr BF (2007) Heterotrophic dinoflagellates: a significant component of microzooplankton biomass and major grazers of diatoms in the sea. Mar Ecol Prog Ser 352:187-197

Editorial responsibility: Marsh Youngbluth,

Fort Pierce, Florida, USA
Sherr EB, Sherr BF, Hartz AJ (2009) Microzooplankton grazing impact in the western Arctic Ocean. Deep-Sea Res II 56:1264-1273

> Slagstad D, Ellingsen IH, Wassmann P (2011) Evaluating primary and secondary production in an Arctic Ocean void of summer sea ice: an experimental simulation approach. Prog Oceanogr 90:117-131

Smidt ELB (1979) Annual cycles of primary production and of zooplankton at southwest Greenland. Greenl Biosci $1: 1-56$

Steemann-Nielsen E (1958) A survey of recent Danish measurements of the organic productivity in the sea. Rapp Cons Int Explor Mer 144:92-95

Stoecker D, Guillard RRL, Kavee RM (1981) Selective predation by Favella ehrenbergii (Tintinnia) on and among dinoflagellates. Biol Bull 160:136-145

Stoecker DK, Gifford DJ, Putt M (1994) Preservation of marine planktonic ciliates: losses and cell shrinkage during fixation. Mar Ecol Prog Ser 110:293-299

Storr-Paulsen M, Wieland K, Hovgard H, Ratz HJ (2004) Stock structure of Atlantic cod (Gadus morhua) in West Greenland waters: implications of transport and migration. ICES J Mar Sci 61:972-982

Stroeve J, Holland MM, Meier W, Scambos T, Serreze M (2007) Arctic sea ice decline: faster than forecast. Geophys Res Lett 34:L09501, doi:10.1029/2007GL029703

> Strom SL, Postel JR, Booth BC (1993) Abundance, variability, and potential grazing impact of planktonic ciliates in the open sub-Arctic Pacific Ocean. Prog Oceanogr 32: 185-203

Tang KW, Nielsen TG, Munk P, Mortensen J and others (2011) Metazooplankton community structure, feeding rate estimates, and hydrography in a meltwater-influenced Greenlandic fjord. Mar Ecol Prog Ser 434: $77-90$

Tremblay JE, Gagnon J (2009) The effects of irradiance and nutrient supply on the productivity of Arctic waters: a perspective on climate change. In: Nihoul JCJ, Kostianoy AG (eds) Influence of climate change on the changing Arctic and Sub-Arctic conditions. NATO Science for Peace and Security Series C: Environmental Security. Springer, Houten, p 73-93

> Turner J, Levinsen H, Nielsen TG, Hansen BW (2001) Zooplankton feeding ecology: grazing on phytoplankton and predation on protozoans by copepod and barnacle nauplii in Disko Bay, West Greenland. Mar Ecol Prog Ser 221:209-219

> Uye S, Aoto I, Onbé T (2002) Seasonal population dynamics and production of Microsetella norvegica, a widely distributed but little-studied marine planktonic harpacticoid copepod. J Plankt Res 24:143-153

Verity PG Langdon C (1984) Relationships between lorica volume, carbon, nitrogen, and ATP content of tintinnids in Narragansett Bay. J Plankton Res 6:859-868

> Verity PG, Wassmann P, Frischer ME, Howard-Jones MH, Allen AE (2002) Grazing of phytoplankton by microzooplankton in the Barents Sea during early summer. J Mar Syst 38:109-123

Yentsch CS, Menzel DW (1963) A method for the determination of phytoplankton chlorophyll and phaeophytin by fluorescence. Deep-Sea Res 10:221-231

Submitted: September 26, 2012; Accepted: December 17, 2013 Proofs received from author(s): February 26, 2014 